\title{
PROSIDING 2018
}

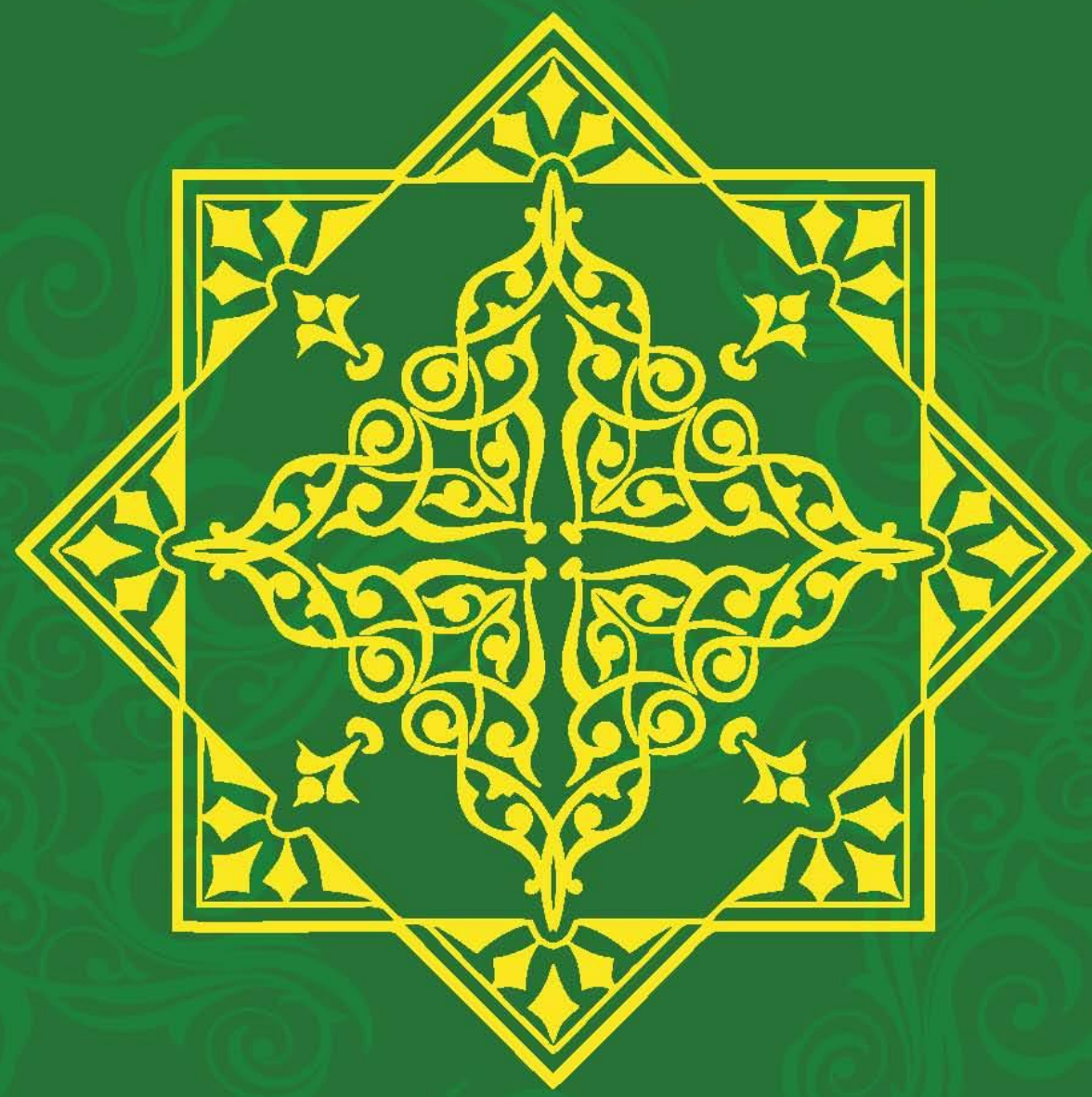

MUKTAMAR PEMIKIRAN SANTRI NUSANTARA

Islam, Kearifan Lokal dan Tantangan Kontemporer 


\section{PROSIDING MUKTAMAR PEMIKIRAN SANTRI NUSANTARA 2018}

"Islam, Kearifan Lokal dan Tantangan Kontemporer"

PP Krapyak, Yogyakarta, 10 - 12 Oktober 2018

Penerbit:

Direktorat Pendidikan Diniyah dan Pondok Pesantren Direktorat Jenderal Pendidikan Islam Kementerian Agama Republik Indonesia 


\section{PROSIDING}

\section{MUKTAMAR PEMIKIRAN SANTRI NUSANTARA 2018}

"Islam, Kearifan Lokal dan Tantangan Kontemporer"

PENGARAH : KAMARUDDIN AMIN

(Direktur Jenderal Pendidikan Islam)

PENANGGUNG JAWAB : AHMAD ZAYADI

(Direktur Pendidikan Diniyah dan Pondok

Pesantren)

KOMITE PELAKSANA

Ketua

: Ainurrofiq

Sekretaris

: Agus Umar

Anggota

: Winuhoro HB.

Bambang Setyawan

Divisi Kesekretariatan : Zaki Kurniawan Apang Sopandi

Divisi Akomodasi

: Heri Mulyana

Ummi Fadhilah

Divisi Dokumentasi dan : Abdul Manan

Publikasi

Brurry Haryanto

Divisi Administrasi dan : Ningrum Mudi Pertami

Keuangan

Sri Wahyuni

Divisi Acara

: A. Rofiq Zainul Mun'im

Hery 


\section{Prosiding}

Muktamar Pemikiran Santri Nusantara 2018

Islam, Kearifan Lokal

dan Tantangan Kontemporer

Reviewer:

Mohamad Yahya, M.Hum.

Mohammad Andi Hakim, M.Hum.

Editor:

Muhamad Sofi Mubarok, M.H.I.

Debi Fajrin Habibi, M.Pd.

Theguh Saumantri, M.Phil.

Jefik Zulfikar Alhafizd, M.H.

Sampul dan Tata Letak:

Abdu Zikrillah, M.Ds.

Hak Cipta Dilindungi Undang-Undang

Copyright @ 2019

ISBN: 978-623-90176-1-3

Diterbitkan Oleh:

Direktorat Pendidikan Diniyah dan Pondok Pesantren

Direktorat Jenderal Pendidikan Islam

Kementerian Agama RI

Alamat Penerbit:

Jalan Lapangan Banteng Barat No. 3-4

Jakarta Pusat 10710

Phone: +62 213811810 


\title{
KATA PENGANTAR
}

\section{"MENJAWAB TANTANGAN KONTEMPORER DENGAN KEARIFAN LOKAL KHAS PESANTREN"}

\author{
Dr. H. Ahmad Zayadi, M.Pd. \\ Direktur Pendidikan Diniyah dan Pondok Pesantren
}

Dalam magnum opus-nya, Nahnu wa al-Turats (1981), M. Abed alJabiri (w. 2010) mengawali diskusinya dengan beberapa pertanyaan mendasar tentang turats, diantaranya adalah kaifa nata'amal ma'a turatsina? (bagaimana kita berinteraksi dengan tradisi kita [dalam kehidupan kontemporer]?). Pertanyaan tersebut menghasilkan paradigma pembacaan ambisius berupa ja'l al-maqru' mu'ashiran li-nafsih wa mu'ashiran lana (aktualisasi objek bacaan di eranya dan di era kehidupan kontemporer) dengan dua langkah metodis, al-fashl dan al-washl. Dalam konteks Islam Indonesia, bagaimana tantangan kehidupan keagamaan hari ini dapat disikapi? Apakah keberadaan kearifan lokal dapat menjadi referensi dalam menjawabnya? Atau kita tidak lagi perlu melihatnya sebab tuntutan zaman sudah berubah?

Dalam menjawab pertanyaan-pertanyaan mendasar tersebut, umat Islam di Indonesia, menurut Ahmad Baso (2006), terbelah menjadi dua tipologi, yaitu post-tradisionalisme dan neo-modernisme. Tipologi kedua mengabaikan sama sekali posisi dan peran turats (baca: kearifan lokal) dengan jargon populernya "al-ruju' ila al-Qur'an wa al-sunnah" (kembali ke alQur'an dan sunnah). Sebaliknya, tipologi pertama sangat menghormati posisi dan peran turats (kearifan lokal) dalam merespon dan menjawab tantangan kehidupan kontemporer. Sebab, bagi kalangan post-tradisionalis ini, nilai-nilai kerifan dalam tradisi dapat selalu lestari dalam mengadapi tantangan kehidupan yang dinamis. Pola ini dikenal dengan paradigma al-muhafadzah 'ala al-qadim al-shalih, wa al-Akhdz bi al-jadid al-Ashlah (melestarikan tradisi [kearifan lokal] yang baik, dan mengakomodir pembaharuan yang dianggap lebih baik).

Sebagai salah satu wajah Islam Indonesia yang genuine, pesantren memiliki posisi strategis dalam kehidupan keagamaan masyarakat Indonesia. Meskipun Gus Dur (w. 2009) menempatkan pesantren sebagai sebuah subkultur dengan tiga cirinya berupa pola kepemimpinan yang berada di luar kepemimpinan pemerintahan desa, literatur universalnya yang terus dipelihara selama berabad-abad, dan sistem nilainya sendiri yang terpisah dari yang diikuti oleh masyarakat, tetapi pesantren selalu berada di garda depan dalam menjawab tantangan kehidupan keagamaan masyarakat yang teramat 
kompleks. Azyumardi Azra (1997) menegaskan bahwa pesantren memiliki tiga fungsi tradisional, yakni transmisi dan transfer ilmu-ilmu Islam, pemeliharaan tradisi Islam, dan reproduksi ulama. Pada perkembangannya, secara dinamis fungsi pesantren merambah hingga ke posisi sebagai solidaritas dan agen perubahan sosial. Pandangan-pandangan tersebut mengindikasikan bahwa karakter tradisionalitas pesantren sangat siap dan matang dalam menghadapi tantangan kehidupan kontemporer. Pijakanpijakan kearifan lokal khas pesantren menjadi modal besar dalam menghadapi tantangan kontemporer. Gus Dur berujar, tradisionalisme yang masak adalah jauh lebih baik daripada psudo-modernisme yang dangkal.

Para pembaca budiman, prosiding hasil Muktamar Pemikiran Santri Nusantara (MPSN) Tahun 2018 yang telah terbit ini merupakan gambaran orisinal bagaimana pesantren menghadapi tantangan kehidupan kontemporer dengan tetap berpijak pada kearifan lokal khas pesantren yang sudah barang tentu berbasis pada nilai-nilai normatif keislaman. Tema besar dalam MPSN 2018 ini adalah Islam, Kearifan Lokal dan Tantangan Kontemporer. Tema ini dianggap relevan mengingat semakin merebaknya gejala pergeseran dan krisis identitas generasi Muslim milenial, utamanya di perkotaan, yang semakin mendistorsi budaya keagamaan Muslim Indonesia dalam kehidupan berbangsa dan bernegara. Alih-alih peningkatan kualitas keagamaan, krisis kebudayaan dalam beragama ini turut berkontribusi melahirkan pola pemahaman keagamaan eksklusif, radikal, dan ekstremis.

Tema besar tersebut dispesifikasi pada lima subtema: (1) pesantren dan moderasi beragama; (2) pesantren dan perempuan; (3) pesantren dan kebudayaan; (4) revitalisasi keilmuan pesantren; dan (5) bahtsul masa'il pesantren dan inovasi pemikiran. Moderasi beragama merupakan tema strategis dalam menjawab tantangan keagamaan kekinian dalam kehidupan berbangsa dan bernegara. Tema ini sekaligus mempertegas sikap pesantren terhadap ancaman peningkatan tren ekstremisme dalam beragama. Pengarusutamaan gender dalam pemikiran pesantren bukanlah barang baru, tetapi publikasi akan sensitivitas pesantren terhadap isu-isu perempuan harus mendapat perhatian lebih serius. Adapun kebudayaan pesantren merupakan tema strategis sebagai upaya preventif bagi generasi masyakarat Muslim yang belum mengalami pergeseran dan krisis identitas kultural. Sementara itu, dua tema terakhir merupakan peneguhan identitas pesantren sebagai sebuah subkultur. Sebagai subkultur, Gus Dur (2007) sangat optimis jika pesantren memiliki kekuatan potensial menjadi agen vital untuk melakukan perubahan di tengah masyarakat. Untuk mencapai posisi tersebut modal dasar yang harus dipenuhi pesantren adalah kemauan berinovasi dan fleksibelitas, sebab 
tantangan modernitas dalam kehidupan kontemporer akan membuka kesempatan untuk berinovasi.

Atas nama Direktur Pendidikan Diniyah dan Pondok Pesantren, saya mengucapkan selamat atas terbitnya Prosiding MPSN 2018 ini untuk pertama kalinya sebagai suatu torehan sejarah bagi perkembangan literasi pondok pesantren. Tentu saja, ini merupakan suatu upaya berkelanjutan atas perhatian besar Kementerian Agama dalam melestarikan maupun melembagakan khittah pesantren sebagai satu-satunya lembaga pendidikan yang fokus menyelenggarakan pendidikan tafaqquh fid-dîn di Indonesia ini, di samping lembaga dakwah dan pemberdayaan masyarakat.

Akhirnya, saya mengucapkan selamat atas terbitnya Prosiding MPSN 2018 ini. Semoga hal ini menjadi legacy tak ternilai yang manfaatnya dapat kita rasakan bersama, terutama bagi perkembangan pesantren di masa-masa yang akan datang. Selamat membaca, semoga berkah. [] 
KATA PENGANTAR

“ISLAM, KEARIFAN LOKAL DAN TANTANGAN KONTEMPORER"

Prof. Dr. Phil. Kamaruddin Amin, M.A.

Direktur Jenderal Pendidikan Islam

Tantangan pesantren dalam merespon persoalan kebangsaan dan keagamaan dewasa ini semakin kompleks. Menguatnya gerakan radikalisme, ekstremisme dan ideologi Islam Transnasional semakin mendistorsi pemahaman keagamaan Muslim Indonesia yang lekat dengan nilai serta kearifan lokal.

Menguatnya gerakan Islamisme dan Arabisme di Indonesia menjadi bukti terjadinya perlawanan terhadap kecenderungan gaya hidup masyarakat yang hedonis dan sekular. Namun demikian, beberapa kalangan menilai justru terdapat hidden agenda di balik upaya Arabisasi yang belakangan semakin gencar dilakukan kaum radikal dan fundamentalis.

Beberapa penyebab lahirnya ekspresi keberagamaan di kalangan generasi Muslim saat ini bertautan pada tiga hal. Pertama, minimnya pemahaman keagamaan yang dinamis dan toleran pada ruang-ruang virtual. Akar kesadaran dan pemahaman kaum muslim terbentuk secara virtual melalui interaksi maya dan terhubung dengan berbagai disparitas, diskriminasi, hingga konservatisme agama. Akibatnya, para pendakwah yang memiliki pemahaman keislaman yang rigid, konservatif, bahkan cenderung menyerang ruang kearifan lokal dan eksistensi NKRI justru mengisi ruangruang virtual secara massif dan terstruktur. Mereka tampil sebagai idola muslim milenial dan memegang otoritas rujukan keagamaan. Kyai kampung yang justru membawa pesan damai dalam setiap muatan materi dakwahnya perlahan mulai tersingkir.

Kedua, minimnya kesadaran untuk mempelajari agama dari sumber rujukan otoritatif. Mereka lebih suka mempelajari Islam dengan cara yang paling praktis dan enggan berdialektika dengan produk keilmuan masa lalu yang termaktub dalam literatur berbahasa Arab seperti kitab kuning.

Ketiga, konstruk pemikiran dan epistemologi yang tak terbentuk di kalangan Muslim masa kini. Mereka terlanjur meyakini pendapat pemuka agama yang mereka idolakan sebagai sebuah kebenaran mutlak tanpa dikonfirmasi lebih jauh secara ilmiah. Mereka tak terbiasa berdialektika dengan penalaran ilmiah maupun penggunaan metodologi untuk menemukan solusi hukum atas persoalan yang dialami. Termasuk mengetahui dalil dan konteks kemaslahatan apa yang bersarang di dalam pendapat pemuka agama tersebut.

Dalam konteks inilah pengarusutamaan pesantren sebagai subkultur perlu ditingkatkan dengan mendayagunakan kaum santri untuk turut serta 
mengukuhkan identitasnya sebagai agen perubahan sosial, dan medium transfer pengetahuan. Berangkat dari tradisi keberagamaan yang moderat sesuai dengan dogma Sunni yang selama ini dianut kalangan pesantren, kaum santri memperkenalkan suatu pemahaman keagamaan yang segar, dinamis, tak terjebak dalam dualisme ifrath dan tafrith, serta mampu mendamaikan kutub tekstualisme di satu sisi dan liberalisme di sisi lain.

Keberhasilan santri dan pesantren dalam memformulasikan metode pemecahan masalah melalui serangkaian metodologi ilmiah yang dapat dipertanggungjawabkan patut diekspos karena Indonesia tengah berada dalam situasi mengkhawatirkan. Pada beberapa kasus misalnya, hukum yang dihasilkan nalar kaum santri sangat berorientasi pada nilai-nilai futuristik, solutif, sekaligus memuat dimensi kemaslahatan sebagai tujuan di balik pemberlakuan hukum syariah yang tentunya relevan dengan semangat moderasi Islam dan kebutuhan untuk menjaga eksistensi NKRI.

Jika ditelusuri lebih dalam, hanya pesantrenlah satu-satunya lembaga pendidikan yang mampu melahirkan ahli-ahli di bidang keilmuan Islam sekaligus mampu berdialektika dengan zaman (faqihu zamanih). Oleh karenanya, tentu sangat relevan jika Muktamar Pemikiran Santri Nusantara hadir sebagai media untuk mendiskusikan hasil kajian, penelitian, temuan serta kiprahnya di masyarakat untuk memecah problematika kebangsaan dan keumatan.

Muktamar Pemikiran Santri Nusantara pertama yang diadakan ini merupakan suatu ijtihad ilmiah untuk mengupas tiga isu utama berkenaan dengan Moderasi Islam, ulama perempuan (women ulama) dan pembahasan seputar hal-hal keagamaan (bahtsul masail).

Kegiatan Muktamar tahun 2018 telah mampu merumuskan beberapa hal, di antaranya: Mengukuhkan posisi santri dan pesantren sebagai subkultur; Mengetengahkan gagasan moderasi Islam yang selama ini termanifestasikan dalam dogma, olah fikir, hingga model keberagamaan kaum santri; Memetakan tantangan serta langkah-langkah yang diperlukan untuk memecah problematika kebangsaan dan keumatan; Upaya transformasi sosial yang dilakukan santri dan pesantren dalam menjaga eksistensi NKRI dan kearifan lokal; Hal-hal yang diperlukan dalam rangka meningkatkan mutu penelitian serta pengembangan keilmuan pada pondok pesantren.

Kami menghaturkan pula apresiasi mendalam atas kesediaan sejumlah tokoh sebagai narasumber baik dalam dan luar negeri yang mewarnai gelaran Muktamar ini. Khususnya KH. Afifuddin Muhajir (Majelis Masyayikh), KH. Husein Muhammad, Muazzam Malik (Duta Besar Inggris), Malik Ballen (Director Official, Leiden University), Syaikh Bilal Mahmud Afifi Ghanim (alAzhar University), dan Dr. Syaikh Salim Alwan al-Husayny (Darul Fatwa Australia).

Sekumpulan tulisan peserta Muktamar tahun 2018 dibukukan melalui Prosiding Muktamar Pemikiran Santri Nusantara pertama dengan lima chapter, antara lain: Pesantren dan Moderasi Beragama; Pesantren dan Perempuan; Pesantren dan Kebudayaan; Revitalisasi Keilmuan Pesantren; dan Bahtsul Masail Pesantren dan Inovasi Pemikiran. 
Lahirnya prosiding tersebut merupakan bentuk dokumentasi kekayaan khazanah kajian pesantren. Naskah di dalamnya dapat menjadi rujukan bagi dunia untuk mengenal lebih dekat pesantren, melalui sajian data yang research based dan dapat dipertanggungjawabkan secara ilmiah.

Akhirnya segala upaya ini merupakan tekad bersama dalam membangun peradaban dunia melalui penguatan kiprah kaum santri dan pesantren. Semoga Allah Swt. berkenan meridai iktikad baik yang kita lakukan bersama ini. [] 
SAMBUTAN DIREKTUR PENDIDIKAN DINIYAH DAN PONDOK PESANTREN

Dr. H. Ahmad Zayadi, M.Pd.

\section{SAMBUTAN DIREKTUR JENDERAL PENDIDIKAN ISLAM}

Prof. Dr. Phil. Kamaruddin Amin, M.A............................................ iv

DAFTAR ISI

\section{CHAPTER I:}

PESANTREN DAN MODERASI BERAGAMA

KONTRIBUSI KIAI SHOLEH DARAT (1830-1903) DALAM MENEGUHKAN ISLAM WASATHIYAH ISLAM DI NUSANTARA

Abdul Mustaqim

HIDDEN CURRICULUM MODEL'S OF TRANS-INTERNATIONAL PESANTREN BASED ON ISLAMIC MODERATION: A CASE STUDY OF THE PESANTREN SULAIMANIYAH TURKI

Ade Gunawan

PANDANGAN SANTRI ASRAMA PERGURUAN ISLAM (API) PONDOK PESANTREN AL-LUQMANIYYAH YOGYAKARTA TENTANG HUMANISME (PERSPEKTIF TEOLOGI ASWAJA)

Adnan Nuril Anwar.

MEMBANGUN MODERASI BERAGAMA MELALUI NALAR FIKIH MODERAT (STUDI PEMIKIRAN SANTRI MA'HAD ALY SITUBONDO) Ahmad Muzakki.

PESANTREN DAN MODERASI ISLAM: KITAB KUNING, DAKWAH SANTUN, DAN MEDIA

Aly Mashar

COUNTERING RADICAISM PONDOK PESANTREN MAHASISWA ASWAJA NUSANTARA MELALUI PENDIDIKAN MULTIKULTURAL- 
INKLUSIV SEBAGAI UPAYA MEMPERKUAT MODERASI ISLAM DAN KEINDONESIAAN

Desy Putri Ratnasari

ISLAMIC MOOC: PENANGGULANGAN RADIKALISME ONLINE DARI PONDOK PESANTREN

Dyah Ayu Fitriana.

PESANTREN MA'QIL AL-WASATHIYAH FI INDONESIA

Fakhim Hasani

PESANTREN IN THE NEW MEDIA: THE ROLE OF SANTRI AS A COUNTER-NARRATIVE AGENT IN DERADICALIZATION EFFORTS ON SOCIAL MEDIA

Galuh Widitya Qomaro

THE VALUES OF RELIGIOUS MODERATION IN THE SONG SYUBBANUL WATHAN SUNG AT NU-BASED PESANTRENS

Imroatul Hasanah.

STRATEGI PESANTREN TAREKAT DALAM MENANGGULANGI EXTRIMISME DAN RADIKALISME DALAM BERAGAMA

Muhammad Nurush Shobah.

PESANTREN DAN FENOMENA ISLAM NUSANTARA: UPAYA BERAGAMA YANG MODERAT

Muh. Alwi Hs

KONTRIBUSI ALUMNI PESANTREN TERHADAP MODERASI ISLAM DI INDONESIA DALAM DASAWARSA TERAKHIR DAN POTENSI KIAI MUDA KEKINIAN

Muhammad Ulil Abshor

SIKAP INKLUSIF DAN KEARIFAN LOKAL PESANTREN

Rizal Ahyar Mussafa

NILAI-NILAI MODERAT DALAM TAFSIR AL-IBRIZ (KAJIAN ATAS PENGAJIAN AHAD PAGI TAFSIR AL-IBRIZ DI PP. AL-ITQON SEMARANG OLEK MBAH YAIAHMAD HARIS SHODAQOH)

Said Ali Setiyawan.

PERAN PONDOK PESANTREN DALAM MENANAMKAN NILAI PANCASILA UNTUK MEWUJUDKAN TOLERANSI KERUKUNAN ANTAR UMAT BERAGAMA

Suryadi 
PONDOK PESANTREN, KITAB KUNING DAN MODERATISME PEMIKIRAN PONDOK PESANTREN

Ubbadul Adzkiya'

DISSEMINATING ISLAMIC MODERATISM AMONG YOUTH: CASE STUDY OF GUSDURIAN MOVEMENT

Wildan Imaduddin Muhammad

DIMENSI POLITIK PESANTREN SEBAGAI BASIS FORMALISASI DAN PENGARUSUTAMAAN MODERASI PENDIDIKAN ISLAM DI RANAH LOKAL

Zaki Mubarok

\section{CHAPTER II}

PESANTREN DAN PEREMPUAN

KIAI, TRANSFORMASI PESANTREN DAN PENCARIAN MODEL GENDER MAINSTREAMING DI PESANTREN SUBULUSSALAM TULUNGAGUNG

Ahmad Zainal Abidin \& Imam Ahmadi

POLA KOMUNIKASI KEPEMIMPINAN NYAI DI PONDOK PESANTREN MODERN PUTRI LAMPUNG

Fitri Yanti.

NYAI SEBAGAI AGEN PERUBAHAN DALAM PENGEMBANGAN PENDIDIKAN PESANTREN BERKESETARAAN GENDER

Haniaturizqia

MUSLIM WOMAN, MADRASA, PESANTREN AND MEDIAIN INDONESIAN LOCAL CONTEXT: A REFLECTION ON INSTITUTIONAL DEVELOPMENT AND FEMALE REPRESENTATION

Kusmana

DOKTRIN PESANTREN TERHADAP PEREMPUAN (KAJIAN TERHADAP KITAB-KITAB DAN REALITAS PEREMPUAN DI DALAM PESANTREN)

Mohammad Nawir

FIKIH KLASIK DAN PEMBERDAYAAN PEREMPUAN HAID

Muhammad Kudhori

ADABUL MAR'AH ILA AHLIHA: "KONSTRUKSI" PEREMPUAN SALEHAH DALAM TRADISI PESANTREN ABAD XVIII-XIX 
Muhammad Tarobin

DAWRAL-MA'HAD FI-TARBIYAT AL-NISA' WA-DAWRUHUNNA FIBINA' AL-MUJTAMA' WAL-HADHARAH AL-ISLAMIYYAH

Neneng Sulaila, Rizal Firdaus

PRESTASI PEREMPUAN PESANTREN DI PANGGUNG POLITIK DALAM DINAMIKA PEMILIHAN KEPALA DAERAH DI PROVINSI JAWA TIMUR

Nurul Azizah

DISKURSUS BRANDING PONDOK PESANTREN MODERN GONTOR PUTRI 1 TENTANG PEREMPUAN ERA MILENIAL DI INSTAGRAM

Robby Aditya Putra

ZADU AZ-ZAUJAIN, KITAB POTRET KEPRIBADIAN KELUARGA SAKINAH KARYA ULAMA PEREMPUAN PESANTREN

Samsul Arifin

PERAN PESANTREN TERHADAP PENINGKATAN KUALITAS KEPEMIMPINAN PEREMPUAN: IMPLEMENTASI KONSEP STIFIN LEADERSHIP DALAM MANAJEMEN KEPENGURUSAN SANTRI

Sherly Dwi Agustin

PENGARUH PENDIDIKAN PESANTREN TERHADAP PERGERAKAN KAUM PEREMPUAN DALAM MEMPROMOSIKAN ISLAM NUSANTARA

Shofiatun Nikmah.

REPOSISI PEREMPUAN DALAM HISTORIOGRAFI PESANTREN

Siti Rofiah.

PERANAN PESANTREN DALAM PENINGKATAN PEMAHAMAN FIKIH IBADAH WARIA (STUDI KASUS PESANTREN WARIA AL-FATAH DI KOTAGEDE YOGYAKARTA)

Tresna Ghufron Faza, Pepy Marwinata, Ni’matul Fauziah

THE BENEFITS OF GENDER SEGREGATION OFFERED BY PESANTREN ON WOMEN

Umi Farisiyah

PEREMPUAN SEBAGAI PENGGERAK UTAMA EKONOMI MIKRO DALAM LINGKUP PESANTREN

Vena Khumayroh. 
PEREMPUAN SEBAGAI PIMPINAN DAYAH: PELUANG DAN TANTANGANNYA DI ACEH

Zuriah

\section{CHAPTER III}

PESANTREN DAN KEBUDAYAAN

BUDAYA MUTU PONDOK PESANTREN

Abd. Muhith

PRINSIP DALAM MEMILIH PARTAI POLITIK: KAJIAN SYAIR NAHDAH KARYA ABU FAUZY (KH. MA'SHUM SIRODJ) PESANTREN GEDONGAN CIREBON

Angga Marzuki

CONTESTING ISLAMIC DISCOURSES IN SOCIAL MEDIA: THE CHALLENGES AND PROSPECTS OF PESANTREN IN DIGITAL ERA

Annas Rolli Muchlisin

PERAN SANTRI DALAM TANTANGAN KONTEMPORER DI NUSANTARA: Telaah Terhadap Pondok Pesantren As'adiyah Sengkang Sulawesi Selatan Sebagai Distributor Muballigh Terbesar Di Indonesia Timur

Ayyub Muhajad

JALAN LITERASI SASTRAWAN SANTRI

Badrus Shaleh

PESANTREN CIREBON DAN REVITALISASI TRADISI LITERASI (SEBUAH TINJAUAN HISTORIOGRAFIS)

Eva Nur Arovah, Nurhata

THE CHALLENGE ON "PESANTREN" IN TECHNOLOGICAL CULTURE

Fahmy Farid Purnama.

PESANTREN DAN MAGIS DI BANTEN

Fahmi Irfani

EKSISTENSI DAYAH TERHADAP PENDIDIKAN KEAGAMAAN MASYARAKAT LOKAL

Fakhrul Rijal. 
SANTRI TURUN KE JALAN: POTRET PENOLAKAN LIMA HARI SEKOLAH

Fariz Alnizar.

SISTEM NILAI DALAM BUDAYA ORGANISASI DI PESANTREN

Fatah Syukur.

PESANTREN UKIR: MENGGAGAS PESANTREN BERWAWASAN UKIR DI JEPARA

Fathur Rohman

RELEVANSI PENDIDIKAN PESANTREN DI ERA MILENIAL

Firdan Fadlan Sidik.

MENGKRITISI KEADILAN PEREMPUAN DARI BILIK-BILIK PESANTREN

778

Hilmi Ridho

MONOGAMI DI KALANGAN KIAI PESANTREN SALAF

Iksan Kamil Sahri

REPRESENTASI SOSIAL SANTRI DAN KOTA DALAM NOVEL HUBBU KARYA MASHURI (SEBUAH TINJAUAN SOSIOLOGI SASTRA)

Imam Muhtarom

MELIHAT KEMBALI FUNGSI SURAU DAN PESANTREN DI MINANGKABAU: UNTUK SIAPA DAN MAU KE MANA?

In'amul Hasan

AKAR PENDIDIKAN KARAKTER DI PESANTREN SUNDA: GUGURITAN KEPESANTRENAN HAJI HASAN MUSTAPA (18521930)

Jajang A Rohmana

845

ANALISIS DEKONTRUKSI TRADISI PESANTREN SALAF SEBAGAI BASIS TRANSFORMASI DI ERA MODERN

Khoirul Mudawinun Nisa'

873

PESANTREN AND HOSPITALITY: THE ROLE OF PESANTREN IN DISSEMINATING THEOLOGY AND ETHICS OF HOSPITALITY FOR INTERRELIGIOUS RELATIONS

Luthfi Rahman

MELAWAN BUDAYA KEKERASAN SIMBOLIK DALAM PENDIDIKAN AGAMA ISLAM: BELAJAR DARI KEARIFAN LOKAL PESANTREN 
Mohammad Andi Hakim

WAJAH PERFILMAN PESANTREN SEBAGAI WADAH DAKWAH MASA KINI

M Musa Al Hasyim

MERUMUSKAN MUSIK PESANTREN PASCA "PADANG PASIR"

M. Yaser Arafat

MEMBENTUK MASYARAKAT MADANIMELALUI KEBUDAYAAN PESANTREN : STUDI KASUS PONDOK PESANTREN DARUL ULUM BANYUANYAR

Moh. Faiq

KEBIJAKAN PESANTREN: DARI DOMESTIKASI KE AKOMODASI

Mohammad Kosim

REINVENTING EDU-RELIGION BUDAYA SYI'IRAN SANTRI TERHADAP PENGUATAN NASIONALISME MASYARAKAT (MENELADANI DAKWAH ALA KHR. ASNAWI KUDUS)

Muhammad Farid

BELAJAR TOLERANSI DARI PESANTREN DI MAYORITAS NONMUSLIM

Muhammad Irfai Muslim

INTERAKSI SOSIAL PESANTREN: STUDI FENOMENOLOGIS MODEL PEMONDOKAN SANTRI (THULLAB) DI MA'HAD DARUL QURAN WAL HADIS AL-MAJIDIYAH AS-SYAFI'IYAH NAHDLATUL WATHAN Muhammad War'i

KONSTRUKSI SOSIAL-TEOLOGIS RITUAL IJAZAH ASMA ARTHO (UANG AZIMAT) DI PONDOK PESANTREN FATHUL ULUM KWAGEAN PARE KEDIRI

Mukhammad Zamzami

BEUET DAN SEUMEUBEUET: SISTEM NILAI YANG MELESTARIKAN EKSISTENSI DAYAH DI ACEH

Muktasim Jailani

PATRIARCHAL PRACTICES IN PESANTREN (A Cultural Anthropology Study in Dayah Jeumala Amal)

Nadya Utari Sitanggang 
IMPLIKASI PONDOK PESANTREN DARUN NUNTERHADAP PELESTARIAN KEBUDAYAAN SENI SASTRA MELALUI AGENDA ASTRA

Nur Ma'rifatul Jannah

AT-TAQOLID AT-TARBAWIYYAH AN-NAHDLIYYAH: DIROSAH AWWALIYYAH

Prosmala Hadisaputra.

NGAJIKUY! A PESANTREN-BASED SOCIAL MEDIA PLATFORM EXPANDING PESANTREN COMMUNITIES WITH EMERGING DIGITAL TECHNOLOGY AND STAND-ALONE SOCIAL MEDIA FOR MUSLIM SOCIETY

Sahal Sabilil Muttaqin, Mohammad Afrizal

PESANTREN DAN PENANGGULANGAN KONTEN NEGATIF INTERNET

Syafiqah Adhimah, Syafiqiyah Adhimiy

HOTEL SYARIAH BERBASIS PESANTREN: STUDI KASUS PADA HOTEL DALWA SYARIAH PONDOK PESANTREN DARULLUGAH WADDAWAH

Syahrul Hidayat.

HIFZHU DAULAH DALAM PERSPEKTIF MAQASID AL-SYARIAH (Konsep Berbangsa dan Bernegara Pondok Pesantren As'adiyah Sengkang)

Tarmizi Tahir

PESANTREN DI TENGAH MASYARAKAT TRANSISIONAL (STUDI PERAN PENGASUH PESANTREN BAIT AS-SHUFFAH AN NAHDLIYAH DI TENGAH KONFLIK KENDENG REMBANG)

Yuliyatun Tajuddin

HISTORY AND UPDATE OF DAYAH (PESANTREN) IN ACEH

Zulfikar Ali Buto, Hafifuddin

\section{CHAPTER IV}

\section{REVITALISASI KEILMUAN PESANTREN}

GENEALOGY OF ISLAMIC TEACHING AND RELIGIOUSNATIONALISM IN PESANTREN: Analyzing the Five Pillars in PP Nurul Jadid Paiton and Sufism in PP. Salafiyah Syafiiyah Sukorejo Abu Hasan Agus R 
PENDEKATAN SPIRITUALPADA PENDIDIKAN ISLAM DI PESANTREN: Studi pada Program Pencerahan Kalbu di Pesantren Mahasiswa Dar al-Mukhlisin UMI Padang Lampe Sulawesi Selatan Afifuddin, Akramunnisa

REVITALISASI PEMAHAMAN KITAB KUNING MELALUI PENDEKATAN SAINTIFIK DAN PENILAIAN AUTENTIK

Agus Supriyadi

GELIAT ISLAMISME BARU DAN ANCAMAN FIKIH KEINDONESIAAN Ahmad Afrizal Qosim.

REVITALISASI PENDIDIKAN ISLAM INKLUSIF-MODERAT DI PESANTREN BERBASIS KEARIFAN LOKAL (KAJIAN HISTORISSOSIOLOGIS DI INDONESIA)

Ahmad Asysyahru Wardi

PESANTREN DAN PENGEMBANGAN KEILMUAN FALAK

Achmad Mulyadi.

SUNAH MENURUT KH. HASYIM ASY'ARI DALAM RISALAH AHLI SUNAH WA AL-JAMA'AH

Ahmad Solahuddin

REVITALISASI SANAD KEILMUAN DI ERA MILINEAL (Tradisi Sanadan di PP Al-Hasaniyah Teluk Naga Tangerang)

Ahmad Suhendra

REVITALISASI ILMU FIKIH DI PESANTREN:AGENDA MEMPERKUAT KONTRIBUSI TERHADAP EKONOMI ISLAM DI INDONESIA

Ahmad Syakur

PESANTREN DAN PEWARIS INTELEKTUAL WALISONGO: GENEALOGI INTELEKTUAL SUNAN MURIA DI PESANTREN BARENG KUDUS

Ahmad Tajuddin Arafat

KONTEKSTUALISASI KITAB KUNING DAN REVITALISASI TRADISI RISET TRANSFORMATIF PESANTREN DI NUSANTARA

Andik Wahyun Muqoyyidin

PESANTREN DIFABEL: ANTARA PELUANG DAN TANTANGAN (Studi Kasus Implementasi Konsep Pendidikan Inklusif di Yayasan Pondok Pesantren Modern Yatim dan Dhuafa Madania Yogyakarta) 
Anwari Nuril Huda.

STRATEGI PERLAWANAN TEKSTUAL KIAI SHOLEH DARAT: ANALISIS POSKOLONIALISME DALAM PENULISAN TAFSIR FAIDALRAHMÂN Fi TARJAMAH AT-TAFSĪR KALÂMAL-MÂLIKAD-DAYYÂN

Cholid Ma'arif 1431

KEIKHLASAN PADA GURU DAN PENGARUHNYA TERHADAP SEMANGAT BELAJAR SANTRI DALAM PROSES PENDIDIKAN DAN PENGAJARAN DI PONDOK MODERN DARUSSALAM GONTOR

Dede Permana 1447

RADEN NGABEHI RANGGAWARSITA: REPRESENTASI PUJANGGA JAWA SANTRI (NAPAK TILAS SANTRI PONDOK PESANTREN GEBANG TINATAR, TEGALSARI, PONOROGO JAWA TIMUR)

Fatkur Rohman Nur Awalin.

DINAMIKA PERKEMBANGAN ILMU FALAK DI PESANTREN

Fitri Kholilah 1476

REVITALISASI USUL FIKIH MAZHAB SYAFI'I SEBAGAI LANDASAN IJTIHAD KONTEMPORER

Holilur Rohman.

PERAN KAJIAN USHUL FIKIH DALAM MENCETAK PEMIKIR ISLAM YANG MODERAT

Ibnu Hajar.

KITAB MAKNA GANDUL JAWAN DI JAWA PARUH KEDUA ABAD KE-XX: MELESTARIKAN TRADISI DAN MENEGUHKAN IDEOLOGI Jamaluddin

AL-QUR'AN IN THE GUS MUS'S POETRY

Khairul Fuad

FASILITASI PEMAHAMAN ISLAM TOLERAN MELALUI LITERASI PESANTREN

Luluk Nadiyatun Nadziroh

PESANTREN AND MAGIC: A STUDY ON MUJARABAT AND ITS VARIANTS

Mochammad Maola

FRAGMEN ALQURAN DALAM KEBUDAYAAN MAGIS "KAJIAN ATAS SILÂH AL-MU'MIN KARYA KYAI MAHFUDZ SYA'RONI” 
PENERAPAN SISTEM KLASIKAL PESANTREN TRADISIONAL ALMUSRI'MELALUI PROGRAM SOBAT CALAKAN DALAM MEREVITALISASI KEILMUAN PESANTREN DI ERA MODERN

Muhammad Holil.

EPISTEMOLOGI KEILMUAN PONDOK PESANTREN MODERN (STUDI TERHADAP PARADIGMA KEILMUAN DI PONDOK PESANTREN MODERN ISLAM ASSALAAM, PABELAN, KARTASURA, SUKOHARJO)

Muhammad Radya Yudantiasa

FIKIH PESISIR JAWA ABAD KE-19: RISALAH KITAB BELUT DAN KITAB BULUS SEBAGAI COUNTER DISCOURSE FIKIH ULAMA' HARAMAIN

Mahmud Yunus Mustofa

NILAI SIRI' NA PACCE DALAM PENGUATAN KARAKTER PONDOK PESANTREN AN-NAHDLAH MAKASSAR

Marwah

PARADIGMA PROGRESIF FIKIH KONTEMPORER

Maulidi 1673

REVITALISASI METODE PEMBELAJARAN TAFSIR K.H. ASYHARI MARZUQI

Moch. Lukluil Maknun

USHUL FIKIH SEBAGAI KERANGKA BERPIKIR SANTRI MILENIAL DALAM MEMECAHKAN PROBLEMATIKA SOSIAL KEAGAMAAN

Moh. Romli

DINAMIKA AKSARA PEGON SEJAK ERA KOLONIAL HINGGA ERA DIGITAL: STUDI KASUS DI MADRASAH IBTIDAIYAH DARUL ULUM KAUMAN NGEMBALREJO KUDUS

Moh Rosyid.

MEMBUMIKAN GREEN PESANTREN: REVITALISASI KEILMUAN PESANTREN BERBASIS EKOLOGIS

Moh. Mufid

SINERGITAS KECERDASAN DALAM PRAKTEK RIYADHAH DI PESANTREN

Muhammad Ishom el-Saha 
TRADISI SANAD DAN REVITALISASI KEILMUAN PESANTREN: PRAKTEK TRADISI IJAZAH SANAD ALQURANPESANTREN TAHFIZH DAARUL QURAN TANGERANG

Muhammad Bisyri.

MENAKAR BUDAYA LITERASI SANTRI PADA PESANTREN DI ACEH Muhammad lqbal.

MENCIPTAKAN GENERASI ILMUWAN MUSLIM (STUDI KITAB TA'LIMUL MUTA'ALIM KARYA SYEKH AZ-ZARNUJI)

Muhammad Abdur Rochman

KONSTRUKSI SOSIAL PEMBACAAN MANAQIB SYEKH ABDUL QADIR AL-JAILANI (STUDI LIVING SUNNAH DI PONDOK PESANTREN MAMBAUS SHOLIHIN)

Nasrulloh

PENGUATAN KAJIAN FALAK DI PESANTREN

Noor Aflah 1833

KONSEP PENDIDIKAN SUFISTIK DALAM MENANGGULANGI PERILAKU MENYIMPANG REMAJA (TELAAH TERHADAP PEMIKIRAN KH. MUHAMMAD IDRIS JAUHARI DAN PENERAPANNYA DI PONDOK PESANTREN TMI AL-AMIEN PRENDUAN)

Nur Holis 1848

EKSISTENSI PANCA KESADARAN SANTRI DALAM MEMBANGUN NASIONALISME PESANTREN: TELAAH PEMIKIRAN KH ZAINI MUN'IM PONDOK PESANTREN NURUL JADID

Nurul Azizeh.

PENERJEMAHAN KITAB JAWI-PEGON: AGENDA BARU JARINGAN PESANTREN (INSPIRASI DARI QS. AN-NISA/04: 09)

Rizki Ulfahadi.

KONTRIBUSI AKSARA PEGON DALAM PERKEMBANGAN INTELEKTUAL ISLAM DI INDONESIA

Sahal Mahfudh

EXPLORING GENUINE THOUGHT OF PESANTREN TO COMBATING RELIGIOUS RADICALISM (THE CASE STUDY OF FIKIH SOCIAL KH SAHAL MAHFUDH)

Sholahuddin 
NALAR KEILMUAN INTELEKTUAL PESANTREN: POTRET PROBLEM DIKOTOMI KEILMUAN DAN PENGEMBANGAN INTEGRASI KEILMUAN PONDOK PESANTREN DI JEMBER

Shoni Rahmatullah Amrozi.

AL-FIQH AL-PESANTREN BI-AB'AD JADIDAH: MINAL-FIQH AL'ANAFY ILAL-FIQH AL-LA'ANAFY

Syamsuri

SEGRESI EPISTEMOLOGI BAHASA ASING DI PESANTREN DALAM KONTEKS ETNOGRAFI KOMUNIKASI

Wahyu Hanafi Putra

AFKAR ASY-SYAIKH ABD AL-KARIM AMRULLAH - MUASIS MA'HAD AT-THUWALIBI PADANG PANJANG SUMATERA GHORBIYAH - AL-ISHLAHIYAH MIN KHILALI KITABATI WALADIHI ASY-SYAIKH ABD MALIK KARIM AMRULLAH (BUYA HAMKA)

Yendri Junaidi

REVITALISASI KEILMUAN PESANTREN DI ERA MILENIAL

Zanuar Mubin

\section{CHAPTER V}

BAHTSUL MASAIL PESANTREN DAN INOVASI PEMIKIRAN

TANWIRUL AFKAR: KOMPARASI BAHTSUL MASA'IL QAULIY DAN MANHAJIY

Abdul Aziz.

REKONSTRUKSI NARASI KEBANGSAAN PESANTREN: FIKIH KEBANGSAAN DALAM FORUM BAHTHUL MASAIL

Ahmad Karomi

KRITIK EPISTEMOLOGIS TERHADAP BAHTSUL MASAIL:

MENGGUGAT HEGEMONI KITAB FIKIH

Akhmad Sulaiman, Muhammad Sa'dullah

COLLABORATIVE GOVERNANCE PESANTREN DALAM MEWUJUDKAN KECERDASAN FINANSIAL UNTUK MEMBANGUN KEMANDIRIAN UMAT

Faizatul Ansoriyah 
PENTINGNYA PERAN ILMU ALAT

Fitriana Rohmatun.

PENINGKATAN BERFIKIR KRITIS SANTRI MELALUI KEGIATAN BAHTSU AL-MASA'IL (STUDI MULTI KASUS DI PONDOK PESANTREN AN-NUR II AL-MURTADLO MALANG DAN PONDOK PESANTREN MAMBAUS SHOLIHIN GRESIK)

Husniyatus Salamah Zainiyati, Nur Azzah Fathin

2056

KONTEKSTUALISASI KITAB KUNING; ANALISA HASIL PUTUSAN BAHTSUL MASÂIL PWNU JATIM TENTANG WAWASAN KEBANGSAAN

Ibnu

KONTRIBUSI BAHTSUL MASAIL PESANTREN DI MADURA DALAM MENGHADAPI PERKEMBANGAN HUKUM ISLAM KONTEMPORER

Kudrat Abdillah

SANTRI TAHFIDZ DAN GALAU: UPAYA SANTRI TAHFIDZ DALAM MENGHILANGKAN PERASAAN GALAU DI PONDOK PESANTREN DARULLUGAH WADDAWAH PASURUAN

M. Alfi Fakhrudin

BAHTSUL MASA'IL PESANTREN DAN INOVASI KEILMUAN: UPAYA MEMASYARAKATKAN BAHTSUL MASA'IL DI ERA MODERN

Miftahul Alim

VIRTUAL "NGAJI IHYA": THE CASE OF ULIL ABSAR ABDALLA'S CIRCLE AND RELIGIOUS NEGOTIATION

Muhammad Saifullah

BAHTSUL MASA'IL PROGRESSIF DAN CIVIL EFFECT DALAM HALAQAH FIKIH DISABILITAS PUSAT STUDI DAN LAYANAN DISABILITAS (PSLD) UNIVERSITAS BRAWIJAYA MALANG

Muhaimin

PRINSIP EKO-HUMANISME DALAM PESANTREN

Muhamad Iqbal

MENCIPTAKAN GENERASI ILMUWAN MUSLIM (STUDI KITAB TA'LIMUL MUTA'ALIM KARYA SYEKH AZ-ZARNUJI)

Muhammad Abdur Rochman 
BAHTSUL MASAIL PENDIDIKAN DINIYAH FORMAL ULYA PONDOK PESANTREN SALAF APIK KAUMAN KALIWUNGU KENDAL JAWA TENGAH DAN INOVASI PEMIKIRAN DALAM MERESPONS DINAMIKA HUKUM ISLAM DI TENGAH MASYARAKAT Muhammad Arifin.

INOVASI PEMIKIRAN: KAJIAN HUKUM JUAL BELI BIOGAS TINJA MANUSIA DALAM PERSPEKTIF FIKIH-KIMIA

Muhammad Wahyu Arif Wibowo, Mahin Muqoddam Assarwani

TAWARAN FIKIH FUTUROLOGI: UPAYA PENETAPAN HUKUM ISLAM DALAM BAHTSUL MASAIL PESANTREN

Muslihun

BAHTSUL MASAIL DALAM EPISTEMOLOGI DIHLIZ AL-GHAZALI: MENAJA FIKIH YANG INKLUSIF-PRODUKTIF

Robbah Munjiddin Ahmada

TATA KELOLA SUMBER DAYA MANUSIA "SANTRI NUSANTARA": SEBUAH PERSPEKTIF EKSPLORATIF

Rumtini Iksan

APLIKASI PENDIDIKAN QUR'ANI DI TMI PONDOK PESANTREN AL AMIEN PRENDUAN

Taufikurrahman.

PESANTREN SEBAGAI MINIATUR PUSAT USAHA DAN PEMBERDAYAAN EKONOMI AGRIBISNIS BANGSA INDONESIA

Villatus Sholikhah, Nurul Anam.

FIKIH LINTAS MADZHAB: ALTERNATIF TERHADAP EKSLUSIVISME MADZHAB KAUM SANTRI DI ERA POST-TRUTH

Zakiul Fuady Muhammad Daud 


\title{
REVITALISASI METODE PEMBELAJ ARAN TAFSIR K.H. ASYHARI MARZUQI
}

\author{
Moch. Lukluil Maknun \\ Balai Litbang Agama Semarang \\ lukluilmaknun84@gmail.com
}

\begin{abstract}
Abstrak
Kajian ini bertujuan mendeskripsikan metode tafsir Alquran yang digunakan oleh Alm. K.H. Asyhari Marzuqi pengasuh pondok pesantren Nurul Ummah Kotagede Yogyakarta yang dapat dijadikan alternatif metode pembelajaran tafsir. Secara kualitatif kajian ini menjawab dua permasalahan yang dibatasi pada; Pertama, metode pengajaran Alquran dan tafsir oleh K.H. Asyhari Marzuqi. Kedua, menyajikan poin-poin pemikiran dari buku tafsir ringkas "Targhibu l-Khatir" karya K.H. Asyhari Marzuqi. Dalam proses pengumpulan data, ada dua sumber data utama yang digunakan, yaitu buku tafsir "Targhibu 1-Khatir" dan hasil observasi dan wawancara kepada warga pesantren Nurul Ummah. Hasil kajian yang didapatkan; Pertama, metode pembelajaran Alquran dan tafsir yang diterapkan K.H. Asyhari Marzuqiyaitu melalui proses sorogan dan klasikal, dengan corak pembelajaran tafsir yang bersifat tahlili menurut Ahlussunnah. Kedua, poin penting dari buku tafsir "Targhibu I-Khatir" adalah, pembaca Alquran setelah dapat membaca dengan baik lafaznya hendaknya meningkatkan pembacaannya secara tahlili yaitu dengan mengetahui artinya, memahami maksudnya, men-tadabburi, dan berusaha mengamalkannya.
\end{abstract}

Kata Kunci: Metode Pembelajaran Tafsir, Tafsir Tahlili, K.H. Asyhari Marzuqi. 


\section{Pendahuluan}

Ada masa tertentu dalam sejarah, bisa jadi termasuk masa hidup penulis, masih ditemukan banyak ulama yang lebih banyak menyampaikan kiprahnya dalam budaya lisan, bukan tulisan, sementara jaman semakin bergerak ke masa budaya tulis dan literasi. Oleh karenanya, penulisan studi tokoh menjadi penting untuk dilakukan. Relevansi studi tokoh jaman milenial ini setidaknya memiliki tiga relevansi. Pertama, mengungkapkan hal-hal yang menarik dari seorang tokoh untuk melihat sejarah di masanya. Kedua, studi tokoh dapat dijadikan pijakan memulai gagasan yang lebih besar di masa depan berdasar ide-ide tokoh sebelumnya. Ketiga, sebagai seleksi validitas perkembangan berbagai penemuan, bahwa gagasan tokoh terdahulu dapat diukur dan diklaim sebagai penemuan baru atau sebaliknya. ${ }^{1} \mathrm{~K}$ ajian ini, dengan kerendahan hati penulis, diharapkan sebagai salah satu usaha lanjutan dari penulisan biografi tokoh Almarhum K.H. Asyhari Marzuqi, pengasuh Ponpes Nurul Ummah Kotagede Yogyakarta, yang salah satunya sudah diterbitkan dalam buku biografi. Di sana disebutkan bahwa salah satu kiprah penting dari almarhum adalah tentang Alquran dan tafsir. ${ }^{2}$ Di antara hasil tulisan peninggalan almarhum yang dapat dikaji adalah buku Targhibul Khatir: Memikat Hati dengan Alquran, sebuah tafsir ringkas surat Alfatihah, juz 30, juz 29, dan juz 28 yang telah disusun dan terbitkan oleh penerbit Ponpes Nurul Ummah.

Buku Targhibul Khatir tersebut oleh almarhum tidak disebut sebagai buku tafsir, melainkan dengan judul "memikat hati dengan Alquran", meskipun di dalamnya merupakan kajian tafsir. Barangkali hal ini juga sebagai peringatan dan teladan cara bersikap terhadap ambiguitas tafsir. Di satu sisi, terdapat hadis Nabi yang memperingatkan bagi siapa saja yang menafsiri Alquran dengan akalnya, ia telah mempersiapkan tempat duduknya di neraka. Ditambah lagi adanya persyaratan menjadi seorang mufassir yang demikian beratnya. Sedangkan di sisi lain Alquran diyakini sebagai petunjuk umat Islam. K.H. Asyhari Marzuqi mencontohkan sikap bahwa menafsiri Alquran sangat tidak mudah, tetapi usaha dan belajar memahami Alquran merupakan tugas setiap muslim. ${ }^{4}$

1 Syahrin Harahap, Metodologi Studi Tokoh \& Penulisan Biografi (J akarta: Prenada, 2011), 1, 10-11.

2 Mahbub J amaludin dan Abdul Basith Rustami, editor. Mata Air Keikhlasan: Biografi K.H. Asyhari Marzuqi (Yogyakarta: Nurma Media Idea, 2009), 121-125.

${ }^{3}$ Asyhari Marzuqi. Targhib Al-Khatir Fi Al-Qur'an: Memikat Hati dengan AlQur'an (Yogyakarta: Nurma Media Idea, 2002).

4 /bid., xvi-xvii. 
Selain tergambar dalam buku Targhibul Khatir, cara pembelajaran Alquran dan tafsir oleh K.H. Asyhari Marzuqi dapat pula dilihat dan dilengkapi dengan metode yang diterapkan semasa hidupnya terhadap para santri di Ponpes Nurul Ummah. Buku tersebut pada dasarnya merupakan kumpulan artikel almarhum dalam agenda Studi Intensif Alquran yang diselenggarakan Universitas Islam Indonesia pada beberapa tahun yang silam, sekitar tahun $1994^{5}$. Sedangkan pembelajaran Alquran dan tafsir terhadap santri terus dilakukan hingga akhir hayatnya, tahun $2004 .{ }^{6}$ Kajian ini dianggap perlu dengan dasar bahwa selain mengungkap pemikiran K.H. Asyhari Marzuqi dalam hal tafsir, juga karena metode yang digunakan dapat dianggap sebagai pilihan metode pembelajaran yang dapat digunanakan pada masa sekarang.

Ada banyak hal yang dapat dikaji dari biografi tokoh dan karyanya. Akan tetapi, dalam kajian yang penulis lakukan dari tahun 2012 hingga 2018 dengan intensitas sesuai kebutuhan data ini, permasalahan dibatasi pada dua hal. 1) Metode pembelajaran Alquran dan tafsir yang diterapkan K.H. Asyhari Marzuqi. 2) Poin pemikiran yang dapat diungkap dalam buku Targhibul Khatir Filquran.

\section{Tafsir, Ilmu Tafsir, Takwil, dan Hermeneutik}

Tafsir secara bahasa bermakna 'penjelasan' atau keterangan yang menjelaskan hal yang tidak jelas pengertiannya, sedangkan takwil bermakna 'kembali' atau juga pengendalian dan pengaturan. Tafsir dan takwil dapat dianggap sinonim oleh beberapa ulama, dan ada pula yang membedakannya. ${ }^{7}$ K.H. Asyhari Marzuqi menyebutkan, titik penekanan tafsir adalah pemahaman manusia terhadap ayat-ayat Alquran sedapat mungkin hingga sesuai dengan yang dikehendaki Allah. Untuk 'takwil', KH Asyhari mengutip Raghib Al-Asfahani yang menyatakan bahwa tafsir lebih umum yang pemakaiannya pada hal yang lafdzi dan per-suku kata, sedangkan takwil pada

${ }^{5}$ Prakata Rektor UII, Prof. Dr. Zaini Dahlan, MA, dalam buku Spiritualitas Alquran dalam Membangun Kearifan Umat, diedit oleh Moh. Mahfud MD, (Yogyakarta: UII Press, 1997) memberikan keterangan bahwa Studi Intensif Alquran (SIQ) dilakukan sejak 1994, yang awalnya diwajibkan bagi semua dosen UII sebelum memperoleh jabatan fungsional pertama. Kumpulan artikel dalam SIQ kemudian dibukukan menjadi bunga rampai, yang di dalamnya juga memuat nama-nama dosen atau penulis luar UII.

6 Mahbub J amaludin, op. cit., 191.

${ }^{7}$ Penjelasan makna dan pengertian terkait perbedaan kata dan istilah ini tentu banyak sekali dijumpai, di antaranya misalnya dalam Ahmad Syurbasyi, Studi tentang Sejarah Pekembangan Tafsir Alquran Al-Karim, (J akarta: Kalam Mulia, 1999), 7-13; Mohammad Arja Imroni, Konstruksi Metode Tafsir Alqurthubi, (Semarang: Walisongo Press: 2010), 4-5. 
hal-hal maknawi dan persusunan kata. Adapun istilah 'ilmu tafsir' dimaknai sebagai ilmu yang mempelajari persoalan-persoalan yang berkaitan dengan Alquran seperti sebab turun ayat, tempat dan waktu turunnya, nasikhmansukh, dan lain sebagainya. Dalam kepentingan kajian ini, istilah tafsirlah yang dipilih, karena dianggap lebih sesuai. ${ }^{8}$

Tafsir dan ilmu tafsri sudah mengalai sejarah perkembangannya sendiri dengan berjalannya waktu dan umat Islam. ${ }^{9}$ Banyak ragam metode dan corak tafsir,di antaranya adalah; a) tahlily (mengurai) atau tajzi'iy (parsial) yang menafsirkan ayat-ayat dari berbagai segi, ayat demi ayat, b) ijmaly (global) yang menafsirkan secara global dan singkat, c) muqaran (komparatif) yang membandingkan ayat, dengan hadits, atau pendapat para ulama, d) maudluiy (tematik) atau tauhidiy yang menyajikan penafsiran pertopik. ${ }^{10}$

Ada berbagai cara yang digunakan Alquran dalam membimbing manusia, antara lain: mengajarkan tata cara beribadah secara langsung, mendeksripsikan mikrokosmos dan makrokosmos secara global, mengajukan pertanyaan yang mengajak manusia berpikir, membuat perumpamaan, mengajukan kritikan pemikiran/perilaku menyimpang, melalui i'jaz sastrawinya, atau ada pula yang melalui kisah yang mengandung banyak ibrah untuk diikuti atau dicermati. ${ }^{11}$ Muhammad Abduh ${ }^{12}$ menggarisbawahi bahwa dialog Alquran dengan masyarakat awam berlaku untuk setiap masa, oleh karenanya tiap orang berkewajiban memahami Alquran sesuai kemampuan masing-masing. Abduh menambahkan, dalam memahami Alquran perlu melibatkan peranan akal dan sosial. Akal diperlukan untuk menghadapi ayat dalam Alquran dengan argumentasi dan pembuktian logika, meskipun dengan keterbatasan akal. Sedangkan peranan sosial akan mempengaruhi corak pola penafsiran para mufassir sesuai jaman yang dihadapi. Tokoh lain seperti Nashr Hamid Abu Zaid malah menyatakan bahwa teks dapat ditafsirkan

${ }^{8}$ Asyahri Marzuqi, op.cit., xv-xvi.

${ }^{9}$ Lihat misalnya: Ahmad Syurbasyi, op.cit,; M. Quraisy Syihab, Membumikan Alquran: Fungsi dan Peran Wahyu dalam Kehidupan Masyarakat, (Bandung: Mizan, 1992), 71-111.

${ }^{10}$ M. Quraisy Syihab, Tafsir Alquran Al-Karim: Tafsir atas Surat-surat Pendek Berdasarkan Urutan Turunnya Wahyu, (Bandung: Pustaka Hidayah, 1997), v; Mohammad Arja Imroni, op.cit., 6-7.

${ }^{11}$ Ahmad Mudjab Mahalli, "Kisah Pelipur Lara" dalam Spiritualitas Alquran dalam Membangun Kearifan Umat, diedit oleh Moh. Mahfud MD, (Yogyakarta: UII Press, 1997), 307-312; M. Nur Kholis Setiawan, Alquran Kitab Sastra Terbesar, (jogjakarta: eLSAQ Press, 2006).

12 Dalam M. Quraisy Syihab, Rasionalitas Alquran: Studi Kritis atas Tafsir alManar, (J akarta: Lentera Hati, 2006), 21. 
secara terbuka (plural), sehingga dalam setiap rentang waktu dapat terjadi pergulatan perbedaan penafsiran. ${ }^{13}$

Memahami Alquran (sebagai bahasa lain dari tafsir) yang sudah mengikuti jaman yang berkembang mau tidak mau akan berkenalan dengan metode baru pula, tidak lagi harus terpaku pada metode tafsir dasar awal. Metode tafsir kemudian dapat disandingkan dengan metode multi disiplin sesuai keilmuan yang beraneka ragam, karena isi dalam Alquran juga berbicara tentang segala aspek kehidupan. Al-Maraghi menyampaikan bahwa Alquran diturunkan secara kronologis sesuai situasi objektif umat saat diturunkan sehingga informasinya mudah diserap. Sedangkan Fazlur Rahman menyarankan dua hal dalam langkah penafsiran: pertama pencermatan asbabun nuzul untuk diolah menjadi makna universal yang makro (tidak hanya umat saat ayat Alquran turun), dan kedua melakukan objektivasi untuk mencari relevansi makna ayat. Menjadikan kebermaknaan realitas objektif ayat Alquran inilah yang dapat dikaji secara metodologi hermenutika. ${ }^{14}$

Hermenutika dari akar katanya dapat dimaknai sebagai 'menafsirkan, interpretasi, menjelaskan, menerjemahkan, menjadikan dapat dipahami' ${ }^{15}$. Sepintas, teori Hermenutika senada dengan tafsir, atau merupakan istilah lain saja. Metode ini meluas tidak hanya untuk digunakan dalam memahami kitab suci (Alquran), atau dulunya digunakan mengkaji Bibel dalam agama Nasrani, melainkan digunakan pula dalam keilmuan teks lainnya, hingga sastra. Jika tafsir dan ilmu tafsir memiliki kaidah lebih runut dan patron yang rumit, maka Hermeneutika lebih bebas dalam interpretasi ilmiah. Para ilmuwan tafsir generasi baru dalam beberapa segi telah terpengaruh atau menerapkan kaidah hermenutika ini. ${ }^{16}$ Pada akhirnya, dalam bahasa M. Quraisy Syihab,

13 Nashr Hamid Abu zayd, Tekstualitas atas Alquran; Kritik terhadap Ulumul Quran, (J ogjakarta: LkiS, 1993).

${ }_{14}$ Abdul Munir Mulkhan, "Wacana Tafsir Multimedia dan Disiplin" dalam Spiritualitas Alquran dalam Membangun Kearifan Umat, diedit oleh Moh. Mahfud MD, (Yogyakarta: UII Press, 1997), 409-410; Abdul Muqsith Ghazali, et.all., Metodologi Studi Alquran, ( akarta: PT Gramedia, 2009), x-xi.

15 Richard R Palmer, Hermenutika: Teori Baru Mengenai Interpretasi, (Yogyakarta, Pustaka Pelajar, 2005), 3-14.

${ }^{16}$ Beberapa contoh kajian penafsiran Alquran dan Hermeneutik dapat diamati misalnya dalam Fariz Pari, et.all, Upaya Integrasi Hermeneutika dalam Kajian Quran dan Hadis: Teori dan Aplikasi, (Yogyakarta: Lembaga Penelitian UIN Sunan Kalijaga, 2012); Mamat S Burhanuddin, Hermeneutika Alquran ala Pesantren: Analisis terhadap Tafsir Marah Labid Karya K.H. Nawawi Banten, (Yogyakarta: UII Press, 2006); Fahruddin Faiz, Hermenutika Alquran: Tema-tema Kontroversial, (Yogyakarta: eLSAQ Press, 2005). 
bahwa dalam memahami Alquran (menafsirkan), terdapat kebebasan dan pembatasan tertentu yang mengikat. ${ }^{17}$

\section{Metode Pembelajaran}

Dalam dunia pendidikan, manusia adalah subjek dan sasaran pendidikan. Teori dan konsep pendidikan berkembang dan beragam. Kegiatan utama proses pendidikan adalah pelaksanaan strategi pembelajaran yang intinya adalah mendorong, menggerakkan, dan membimbing anak didik untuk belajar dengan potensi yang dimilikinya. ${ }^{18}$

Metode pembelajaran dapat diartikan sebagai cara atau langkah dalam menyampaikan gagasan atau pemikiran untuk mencapai tujuan pembelajaran. Metode ini memiliki peran penting dalam keberhasilan proses mencapai tujuan. Di antara metode pembelajaran yang dapat dilakukan adalah: ceramah, tanya jawab, demonstrasi, penugasan, pemecahan masalah, diskusi, simulasi, eksperimen, dan lain sebagainya. Dalam memilih metode juga perlu diperhatikan faktor tujuan itu sendiri, kondis anak didik, lingkungan, alat, dan kesiapan guru. Berbagai model pembelajaran juga telah banyak dicontohkan, misalnya model CBSA (cara belajar siswa aktif), quantum learning, problem base learning (PBL, berdasar masalah/kasus), atau model kooperatif dan interaktif. ${ }^{19}$ Model dan prinsip pembelajaran ini berlaku tidak hanya untuk pembelajaran di bangku sekolah, melainkan juga termasuk di pesantren, baik pelajaran diniyah secara umum, maupun Alquran dan tafsir pada khususnya.

\section{Profil K.H. Asyhari Marzuqi dan Ponpes Nurul Ummah}

K.H. Asyhari Marzuqi (1942-2004 M), pengasuh Pondok Pesantren Nurul Ummah, merupakan putra pertama K.H. Ahmad Marzuqi Ramli (19011991 M), Giriloyo, Bantul, Yogyakarta. Riwayat pendidikan almarhum, setelah lulus Sekolah Rakyat, melanjutkan belajar di Ponpes Krapyak, Bantul, Yogyakarta, sambil menempuh pendidikan umum hingga lulus dari jurusan tafsir hadis fakultas syariah di IAIN Sunan Kalijaga. Selepas kuliah, almarhum ingin melanjutkan pendidikan pascasarjana syariah di Baghdad, tetapi tidak ada jalur beasiswa, sehingga almarhum belajar di lembaga yang bernama "Kulliyatul Imam al-A'zham", Baghdad, Iraq. Selama di Baghdad, almarhum juga bekerja di kedutaan Indonesia sebagai penerjemah, yang menjadi akses pengetahuan sangat melimpah di sana. Selain di kedutaan, almarhum juga

${ }_{17}$ M. Quraisy Syihab, Membumikan Alquran, op.cit., 75-82 .

18 Abuddin Nata, Perspektif Islam tentang Strategi Pembelajaran, (I akarta: Kencana, 2011), 27-28.

19 Ibid, Trianto, Mendesain Model Pembelajaran Inovatif-Progresif, (I akarta: Kencana, 2011). 
aktif dalam kegiatan organisasi, dan sempat menjadi ketua PPI (Persatuan Pelajar Indonesia) di Baghdad. Hingga pada tahun 1986 almarhum diminta pulang oleh sang ayah dan diminta mengasuh pesantren yang dirintis sang ayah. ${ }^{20}$

Terdapat pengalaman menarik sewaktu masih berada di Ponpes Krapyak yang dapat dianggap sebagai titik tolak K.H. Asyhari Marzuqi dalam menentukan spesifikasi keilmuan yang dijalani. Saat itu K.H. Asyhari ragu mau memilih menekuni hafalan Alquran atau penguasaan kitab. K.H. R. Abdul Qodir menyarankannya agar menghafal Alquran seperti sang ayah (K.H. Marzuqi Romly). Sedangkan K.H. Ali Ma'shum menghendaki agar ia menekuni kitab terutama tafsir: "J ika kamu menguasai kitab dan tafsir, maka Alquran akan serta merta ikut. Akan tetapi, jika kamu hanya menghafal Alquran, belum tentu kitab dan tafsirnya dapat kamu kuasai." Akhirnya K.H. Asyhari muda memilih arahan K.H. Ali Ma'shum. ${ }^{21}$

Pondok pesantren Nurul Ummah dirintis dari usaha $\mathrm{KH}$ Ahmad Marzuqi Romly dalam mencari tempat untuk lahan dakwah putranya, K.H. Asyhari Marzuqi, hingga mendapatkan kesempatan untuk memanfaatkan lahan wakaf di daerah Kotagede. Pesantren ini dibangun setelah kepulangan K.H. Asyhari Marzuqi dari Baghdad, yaitu pada 9 Februari 1986, kemudian diresmikan dan terdaftar oleh Kankemenag Propinsi DIY dengan nomor A. 8655 tertanggal $6 \mathrm{~J}$ uli 1986. Alamat lengkap pesantren Nurul Ummah ada di J. Raden Ronggo KG II/ 982, kelurahan Prenggan, kecamatan Kotagede, Kota Y ogyakarta. ${ }^{22}$

Pondok pesantren Nurul Ummah dibangun secara bertahap dan terus melakukan perluasan dan pembenahan dari tahun ke tahun, sejak masih di bawah pimpinan K.H. Asyhari Marzuqi, hingga di bawah kepengurusan Yayasan. ${ }^{23}$ Hingga saat pengumpulan data dilakukan (2013) luas tanah yang dimiliki PP Nurul Ummah belum dapat dipastikan mengingat terus dilakukan usaha perluasan, tetapi data penelitian $\mathrm{Hamid}^{24}$ pada tahun 2010 disebutkan $3.657 \mathrm{~m}^{2}$.Saat ini, dengan berbagai fasilitas yang dimiliki, paling tidak program Pesantren Nurul Ummah dapat dikelompokkan menjadi; 1) Program informal, yaitu Madrasah Diniyah yang menjadi sokoguru pesantren; 2)

20 Mahbub Jamaludin, op.cit, 27-76; Buku Profil Pesantren Nurul Ummah; Ponpes Nurul Ummah, Manaqib Almagfurlah K.H. Asyhari Marzuqi (https:// www.youtube.com/ watch?v=Y iqks4l7kE8).

${ }^{21}$ Mahbub J amaludin, op. cit., 45-46.

22 Mahbub J amaludin, op.cit, 82-90.

23 Mahbub J amaludin, op.cit, 86-95.

${ }^{24}$ Hamid, "Modal Sosial (Sosial Capital) di Pesantren Nurul Ummah, Studi tentang modal sosial pra dan pasca kepemimpinan K.H. Asyhari Marzuqi." (Tesis Fakultas IImu Sosial dan Politik Sekolah Pascasarjana UGM Yogyakarta, 2010.), 45. 
Program formal, memiliki Madrasah Aliyah (SMU), Madrasah Tsanawiyah (SMP), dan Madrasah Ibtidaiyah (SD); 3) Program pendukung, yaitu kesantrian dan pengembangan bakat. ${ }^{25}$ Adapun jumlah santri, tiap tahun mengalami peningkatan, meskipun tentu juga diimbangi dengan adanya regulasi santri yang keluar/lulus dan santri yang masuk. Hamid ${ }^{26}$ menyebutkan bahwa hingga tahun 2010, kisaran jumlah santri tidak kurang dari 700 orang putra-putri.

Sebagaimana lazimnya pesantren salaf, berkembang-tidaknya pesantren salah satunya dipengaruhi oleh adanya sosok pengasuh (Kiai) yang menjadi panutan bagi para santri. Umumnya sosok Kiai diidentikkan memiliki kharisma yang dapat dirasakan paling tidak oleh santri-santrinya, sehingga para santri merasa betah menuntut ilmu di pesantren itu. Dalam teori modal sosial, K.H. Asyhari Marzuqi memiliki modal sosial yang kuat, seperti kepercayaan, norma, dan kerjasama jaringan. Selain itu, almarhum juga sangat inten dalam melakukan kaderisasi terhadap santri. Kharisma yang dialamatkan kepada masing-masing Kiai menjadi ciri khas yang kemudian dikenal oleh masyarakat, sehingga masyarakat akan mencari sang Kiai untuk menimba ilmu, atau menitipkan anaknya untuk dibina. K.H. Asyhari Marzuqi oleh masyarakat lebih dikenal sebagai Kiai yang memiliki kecakapan dalam bidang tafsir, dan hal inilah yang menjadi daya tarik almarhum dan pesantren Nurul Ummah. ${ }^{27}$

\section{Metode Pembelajaran Alquran dan Tafsir K.H. Asyhari Marzuqi}

Sistem pembelajaran di ponpes Nurul Ummah secara umum dapat dilihat dalam buku profil ponpes Nurul Ummah. ${ }^{28} \mathrm{~J}$ enjang kelas diniyah terdiri dari A waliyah 4 tahun, Wustha 2 tahun, Ulya 2 tahun, dan Forum Kajian A'la (bagi lulusan diniyah). Adapun sistem pengajaran Alquran dan tafsir di ponpes Nurul Ummah menjadi bagian dari pembelajaran tersebut. Meskipun demikian, secara lebih sederhana dapat dilihat dalam pemaparan berikut.

\section{Sistem pengajaran Alquran}

Santri yang masuk ke pesantren Nurul Ummah memiliki bermacam latar belakang, baik daerah asal maupun tingkat pendidikan dan kemampuan.

2018.

${ }^{25}$ www.nurulummah.com.; wawancara dengan Athourrahman, September

${ }^{26}$ Hamid, op.cit, 54.

${ }^{27}$ Hamid, op.cit.; Moch. Lukluil Maknun. "Implementasi Tradisi Ikhtilaf dan Budaya Damai pada Pesantren Nurul Ummah dan Ar-Romli Yogyakarta." J urnal Analisa Vol. 21(02) 2014, 239-251. https://doi.org/10.18784/analisa.v21i02.18, 234; Zamakhsyari Dhofier, Tradisi Pesantren,(J akarta: LP3ES, 1982), 55-60; Sukamto, Kepemimpinan Kiai dalam Pesantren, ( akarta: Pustaka LP3S: 1999).

${ }^{28}$ Profil Pondok Pesantren Nurul Ummah, tt. 
Santri yang diterima adalah pelajar setaraf SMP, SMA, dan Kuliah. Dalam penempatan kelas diniyah, kemampuan santri diuji dengan tes seleksi penempatan kelas, sehingga tinggi rendah tingkat pendidikan umum santri tidak berpengaruh dalam penempatan kelas diniyah.

Adapun sistem pengajaran Alquran yang diterapkan dan dirintis oleh pengasuh di Ponpes Nurul Ummah adalah sistem sorogan dan klasikal. Sorogan Alquran dilaksanakan secara individu setiap hari bakda Subuh kecuali hari J umat dan Ahad kepada pengasuh, untuk kelas Wustha dan Ulya, dan bagi santri Awaliyah kepada para ustaz sesuai kelompoknya dan jadwal yang diatur. Untuk santri Awwaliyah juga mendapatkan program tajwid dan tahsindengan metode Qira'ati yaitu bagi yang belajar mengenal Alquran dari awal, atau telah mendapatkan dasar-dasar Alquran pada riwayat pendidikan sebelumnya kemudian mengulang atau menguatkan kembali dengan panduan dari Pesantren Nurul Ummah.

Bagi santri yang menginginkan untuk mengikuti program tahfiz dengan mempelajari qiraah sab'ah metode yang digunakan adalah unda'an (santri maju menambah hafalan secara langsung kepada pengasuh), deresan (pengulangan bacaan yang sudah dihafal di depan pengasuh sebanyak seperempat juz), dan tekukan (membaca bersama-sama dengan tartil). Tahfiz di Ponpes Nurul Umma dibimbing oleh, H. Agus Muslim Nawawi adik ipar KH Asyhari Marzuki, sedangkan santri putri dibimbing oleh $\mathrm{Hj}$. Barokah isteri almarhum. Untuk menunjang hafalan, diadakan semaan Alquran 30 juz secara individu atau kelompok dalam periode tertentu. Santri yang menekuni program tahfidz juga dikelompokkan dalam asrama/kamar terpisah dengan santri lainnya untuk mempermudah koordinasi dan menjaga suasana tahfidz lebih kondusif.

Di Pesantren Nurul Ummah, santri selain mengikuti program Alquran tersebut, juga diberikan pilihan untuk mengikuti kegiatan tilawah (seni baca Alquran) sebagai salah satu bagian dari wadah seni santri selain kaligrafi, musik dan hadrah, teater, sastra, dan retorika.

2. Sistem pengajaran tafsir

Dalam pengkajian tafsir, sedikitnya ada dua sistem yang dirintis oleh pengasuh, yaitu; Pertama sistem sorogan (santri menyetorkan bacaan beberapa ayat atau surat di hadapan pengasuh/ustadz, diikuti menyetorkan pemahaman atas bacaan yang disetorkan, kemudian dilanjutkan diskusi terkait bacaan). Kedua, sistem bandongan (pengkajian kitab tafsir oleh ustadz yang disimak oleh para santri, dengan sistem satu arah, yakni ustadz berceramah, santri menyimak dengan kitab masing-masing sambil memberikan makna ganduh). 
Pada masa K.H. Asyhari Marzuqi masih mengajar, agenda setelah subuh sampai kira-kira jam 10 pagi adalah pengajian bandongan kitab AlMaraghi, dilanjutkan dengan setoran tafsir klasikal (kelas Wustha dan Ulya) secara bergantian, kemudian setoran tahfiz individu. Dalam pembacaan kitab Al-Maraghi, K.H. Asyhari mengikuti pola yang ada dalam kitab, yaitu pembacaan maqra yang terdiri dari beberapa ayat dengan dibacakan per ayat secara tartil yang diikuti oleh santri, baru kemudian dimaknai perkata secara nahwiyah (makna gandul), pembahasan mufradat, dan syarah perkata atau kalimat. ${ }^{29}$ Pada saat membaca syarah ini, K.H. Asyhari akan memberikan keterangan penjelasan yang bisa saja meluas dari tema, tetapi tetap terkait ayat yang dibahas. Dalam waktu satu jam pelajaran, bisa jadi satu bahasan maqra yang terdiri dari 3-5 ayat (kurang lebih), tidak selesai, dan dilanjutkan hari berikutnya. Hal ini terjadi karena keterangan Kiai sedemikian luas dari hasil muthalaah, pengalaman, pembacaan berita, dan lain sebagainya. ${ }^{30}$

Setelah pengajian tafsir Al-Maraghi, kegiatan berikutnya secara bergiliran adalah setoran tafsir klasikal kelas Wustha dan Ulya (4 kelas). Tiap kelas akan membaca maqra yang berbeda, dimulai secara terbalik dari juz akhir (30-27) yang merupakan juz pokok yang perlu dikuasai santri sebagai bekal untuk terjun bermasyarakat. ${ }^{31}$ Dalam pelaksanaan setoran, dengan urut persensi santri, ada yang bertugas membaca maqra secara tartil per ayat diikuti santri lainnya. Pak Kiai akan membetulkan bacaan terutama kepada yang bertugas membaca. Kemudian ada santri yang bergiliran membaca terjemah Depag. Setelah itu, pak Kiai akan menanyakan kesan yang didapat dari pembaca terhadap maqra, ayat mana yang berkesan, alasannya,

29 Lihat susunan penyajian kitab Ahmad Musthafa Al Maraghi, Tafsir Almaraghi: J uz 14, (Beirut: Dar Ihya at-Turats Al-Araby, 1985).

30 Kiai membiasakan diri untuk selalu muthalaahkitab pembanding sebelum mengajar dan mengaji. Kebiasaan muthalaah ini pula yang ditanamkan kepada para ustaz dan santri. Terkait pembahasan maqra yang lama, banyak santri mengaku bahwa dalam kitabnya terdapat banyak catatan pinggir, sehingga kitab tidak hanya terisi makna gandul saja. Keterangan bisa dari tafsir lain, sejarah, berita, pengalaman Kiai, atau kasus-kasus aktual. Bagi santri yang kurang sabar, bandongan Tafsir AlMaraghi dirasa lambat, karena maqra yang dibaca sedikit. Akan tetapi di sisi lain, santri sangat beruntung, tanpa harus membaca banyak kitab tafsir dan lain sebagainya, sudah mendapat keterangan komprehensif dari Kiai (wawancara dengan J auhar Hilal, 2013 dan Ahmad Mubarok, September 2018).

${ }^{31}$ Ahmad Mubarak juga menyatakan bahwa buku Targhibul Khatir (tafsir juz 30, 29, 38) ini jika dianggap selesai juga bisa, bukan berarti pak Kiai belum melanjutkannya. Pak Kiai memang memberikan penekanan pada juz-juz akhir ini, di dalamnya ada pemantapan tauhid dan dasar bermasyarakat (wawancara, September 2018). 
pembandingan di dalamnya, dan seterusnya. Baru kemudian dilanjutkan diskusi dan penjelasan dari pak Kiai. ${ }^{32}$

Setoran individu santri diterima Kiai setelah setoran tafsir klasikal usai. Urutan dan jadwal setoran individu sebenarnya tidak terlalu terikat, dalam arti menyesuaikan jadwal sekolah atau kuliah santri yang akan setoran. Setoran individu dilakukan utamanya dari para santri yang mengikuti program tahfiz, maupun yang menyetorkan bacaan tartilbi $n$ nazr. Dalam setoran ini, santri juga dimintai menjelaskan makna dan kesan dari maqra yang dibaca. Meskipun dimungkinkan maqra yang dibaca santri satu dengan yang lain sama, tetapi pertanyaan dan ayat yang berkesan bisa jadi berbeda. Dalam hal ini, Kiai sudah menggabungkan pemahaman psikologi terhadap masingmasing santrinya. Sebagai misal, dalam maqra satu santri terarah (diarahkan) pada tema tasawuf, di sisi lain pada tema dakwah, sedangkan santri lain pada tema fikih. ${ }^{33}$

\section{Pembelajaran Alquran dan Tafsir Pasca Wafatnya Almarhum}

Uraian pembelajaran Alquran dan tafsir yang disampaikan sebelumnya adalah metode dan praktek yang dilaksanakan oleh Pengasuh dan uztaz Madrasah Diniyah Nurul Ummah semasa K.H. Asyhari Marzuqi masih hidup. Adapun setelah Kiai wafat, ada beberapa perubahan praktik pembelajaran Alquran dan Tafsir di Nurul Ummah. Beberapa kitab tafsir yang terus dikaji di Ponpes Nurul Ummah sampai pada ajaran 2018/2019 ini sebagai berikut; 1) Kitab yang masuk dalam pembelajaran diniyah yaitu Muqarraru t-Tafsir, untuk kelas III dan IV Awaliyah dan Tafsir Ayat I-Ahkam jilid 1 dan 2, untuk kelas

32 Metode setoran klasikal ini dilakukan setelah santri bertambah serta waktu terbatas, dan dirasa oleh pak Kiai sayang jika keterangan ini hanya dinikmati santri yang sorogan secara individu saja. Ada tiga hal yang perlu disiapkan santri sebelum sorogan ini: 1) apa yang menarik dibaca, 2) pendapat santri terhadap hal yang dianggap penting dan menarik dalam maqra oleh Kiai, 3) perbandingan di dalamnya (baik-buruk, mukmin-kafir, surga-neraka, dan seterusnya). Saat setoran, santri dibebaskan muthalaah dan membawa kitab tafsir sebagai pegangan dan pembandingan, baik tafsir seperti Marah Labid, Jalalain, Al-Ibriz, dan Terjemah Depag (wawancara dengan J auhar Hilal, 2013 dan Ahmad Mubarak, September 2018).

33 Pengalaman informan, pernah saat menyetorkan surat Yasin, santri sebelumnya berkesan pada ayat "Salamun qaulan min Robbi $\mathrm{r}$ rahiim". Kemudian informan yang mendapat giliran setor berikutnya ini dengan maqra yang sama menyatakan ayat serupa sebagai ayat yang berkesan. Ternyata oleh Kiai diarahkan pada ayat lain "wa ja'a rajulun min aqsa 1 madinati yas'aa...". Jika santri sebelumnya ternyata condong dan diarahkan pada bidang tasawuf, santri yang menjadi informan ini ternyata diarahkan pada dakwah. Bahwa di manapun tempat, saat niat dakwah sudah lurus dan ikhlas, akan ada pertolongan dari orang (wawancara dengan Ahmad Mubarak, September 2018). 
Wustha dan Ulya. 2) Kitab tafsir yang dikaji secara bandongan setelah subuh yaitu tafsir J alalain dan Shafwatu t-Tafasir. ${ }^{34}$

Sebenarnya kitab-kitab tafsir yang ada di perpustakaan ndalem yang merupakan koleksi kitab almarhum K.H. Asyhari Marzuqi amat berlimpah. Hal ini karena selain minat baca almarhum yang tinggi, juga kepentingan kemaslahatan kitab itu sendiri untuk selanjutnya dapat digunakan sebagai referensi berliterasi santri Nurul Ummah. ${ }^{35}$ Meskipun demikian, tidak semua kitab tafsir yang ada dalam koleksi Ponpes Nurul Ummah kemudian dikaji dalam pembelajaran diniyah dan bandongan. Sejak dari kebijakan pengasuh saat masih hidup, sudah ada prioritas kitab yang perlu dikajikan dalam pembelajaran diniyah dan ada yang cukup menjadi referensi. Selain itu, terdapat faktor efisiensi waktu yang menyebabkan kitab-kitab tafsir lain tidak dikajikan.

Setelah wafatnya pengasuh, para ustaz dan pengurus meneruskan langkah pengajaran tafsir yang dirintis pengasuh dengan berbagai kompetensi masing-masing. Sebagian kelompok ustaz mengajari sorogan tartil santri dasar (dengan metode terakhir yang dipakai adalah Qiroati, berjenjang jilid) di samping juga santri mengikuti kelas diniyah yang di dalamnya pada kelas dasar diajarkan cara baca tulis huruf pegon. Saat santri sudah dinilai mampu, maka dengan rekomendasi ustaz sorogan, santri tersebut dapat diikutkan kelas tafsir bandongan bersama ustaz senior. Dalam sistem bandongan, ustaz berperan aktif memberikan pelajaran tafsir, dengan membacakan kitab-kitab tafsir yang disesuaikan kurikulum, sementara santri mendengarkan dan memberikan makna pada kitab masing-masing. ${ }^{36}$

Adapun sorogan tafsir individu dan klasikal, baik untuk santri program tahfidz maupun program klasikal kelas Wustho dan Ulya sementara hingga tahun ajar 2018/2019 ini belum dapat dilaksanakan. Hal ini barangkali

34 Buku Profil Ponpes Nurul Ummah, op.cit., dan Wawancara Muhammad Raudak pada September 2018.

${ }^{35}$ Minat baca almarhum sangat tinggi, dapat dilihat dalam buku biografinya, Mahbub J amaludin, op.cit., atau Manaqib Almaghfurlah di Youtube. Pengakuan dan pengamatan santri juga banyak yang membuktikan hal ini, berlimpahnya referensi yang kadang tidak dijumpai di bangku dan perpustakaan kampus. Tidak jarang, dalam pembelajaran, Kiai menitipkan kepada santri jika menemukan buku/kitab baru yang ingin dibaca dan dikoleksinya. Demikian pula, para santri atau alumni juga saat sowan Kiai membawakan oleh-oleh buku baru terutama terkait Alquran dan tafsir akan diterimanya dengan suka cita. Dalam masa-masa akhir hayatnya, Kiai juga pernah titip kepada santri yang sedang berangkat haji untuk dibelikan tafsir AsySya'rowi yang saat itu baru saja terbit jilid akhirnya, (wawancara dengan Ahmad Mubarok, Sept 2018; J auhar Hilal dan Ahmad Suparmin, 2013).

36 Wawancara dengan Ahmad Suparmin, 2013; dengan M. Raudak dan Adrik L M, September 2018. 
disebabkan utamanya karena belum ada ustadz yang merasa mampu memberikan pengajaran yang setotal almarhum. Santri-santri alumni yang sudah boyong dan mengampu pendidikan diniyah atau Alquran, barangkali malah sedikit banyak mengadopsi pola pembelajaran tafsir almarhum ini. Ahmad Mubarok menegaskan bahwa yang dibutuhkan di masyarakat saat ini tidak hanya program baca tulis Alquran dan tahfiz saja, tetapi perlu juga disertai pengajaran tafsir dasar. Sudah barang tentu ustaz yang mengajar juga memiliki kualifikasi sebagai pengajar Alquran dan tafsir, yang memahami ilmu tafsir, dan banyak membaca kitab-kitab tafsir, meskipun dalam pembelajarannya hanya menggunakan Alquran terjemah Kemenag. ${ }^{37}$

\section{Targhibul Khatir Filquran, Deskripsi dan Poin Pemikiran}

Sebelum mendeskripsikan poin-poin pemikiran K.H. Asyhari Marzuqi dalam bukunya, terlebih dahulu dapat dilihat identifikasi buku ini dalam tabel 1.

Tabel 1. Identifikasi Buku Targhibul Khatir Fi Alquran

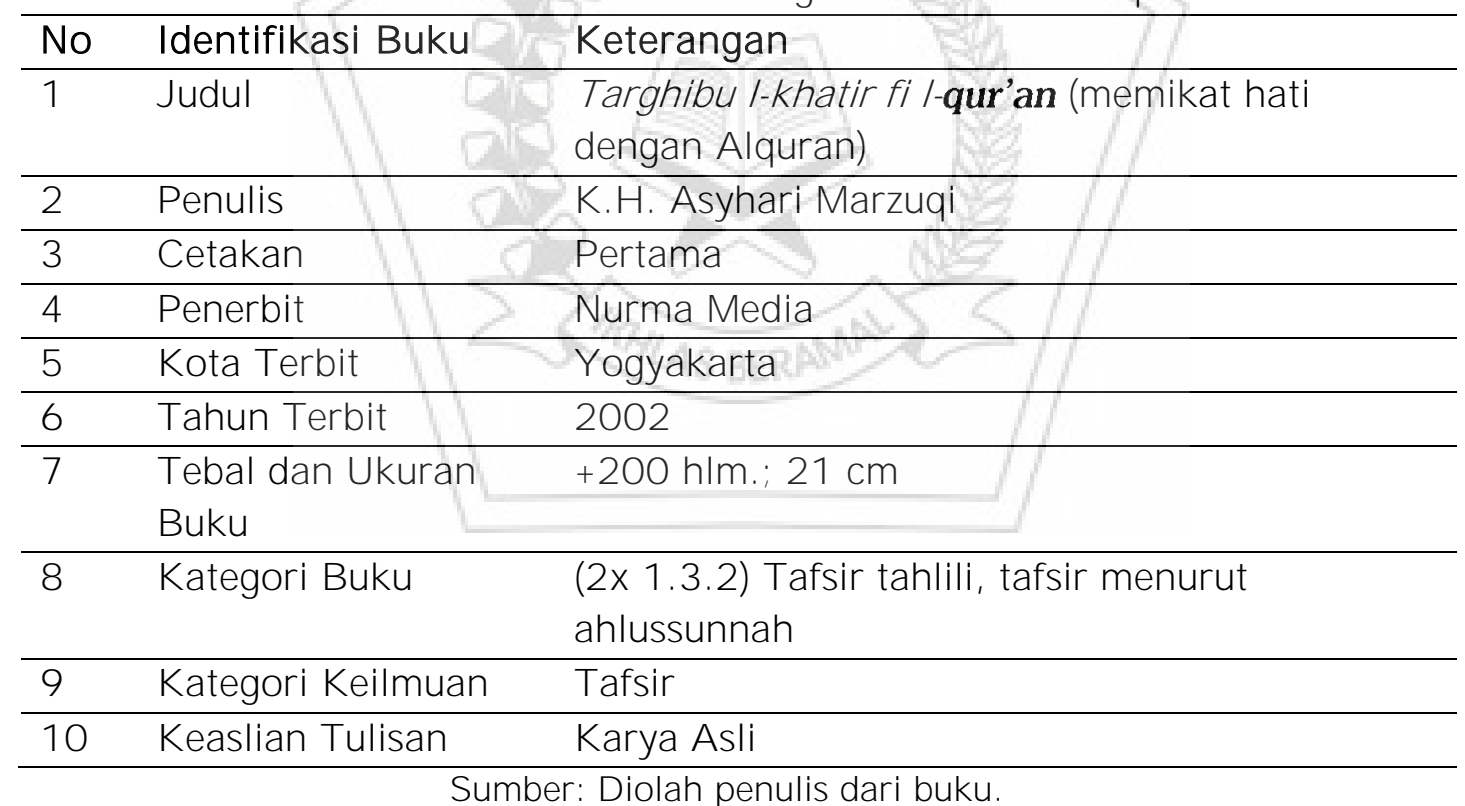

Buku ini terdiri dari empat bagian/bab; 1) Surat Alfatihah, 2) Tafsir J uz 30, 3) Tafsir J uz 29, dan 4) Tafsir J uz 28. Pada bagian pertama terdiri dari: pendahuluan, pembahasan, penafsiran, dan beberapa penjelasan. Sedangkan pada bagian dua hingga empat, masing-masing terdiri dari: pendahuluan, kandungan juz, (hal-hal yang menarik), dan langkah-langkah pengamalan.

${ }^{37}$ Wawancara dengan Ahmad Mubarok, September 2018. 
Pada bagian pertama, K.H. Asyhari Marzuqi memberikan pembahasan surat Alfatihah dengan panjang lebar (hingga separuh buku), sebagaimana para mufassir memberikan perhatian lebih pada surat ini. Sedangkan pada bagian kedua hingga empat, K.H. Asyhari Marzuqi hanya memberikan deskripsi global dan kutipan ringkas, untuk kemudian disarikan dalam langkah pengamalan. Selanjutnya, yang menjadi fokus pembahasan dalam sub ini adalah bagian akhir dari tiap-tiap bab (bagian) buku, yang merupakan hasil pengendapan pemahaman dari K.H. Asyhari Marzuqi.

Model penafsiran K.H. Asyahari Marzuqi dapat digolongkan ke dalam metodetafsir tahlili, yaitu menjelaskan kandungan Alquran dari berbagai segi dengan memperhatikan runtutan ayat ${ }^{38}$. Di satu sisi, jika dikatakan mengadopsi hermenutika pun bisa pula, dengan maksud menghubungkan horizon manusia dengan teks, yang memerlukan ijtihadi dan empati untuk memperoleh pemahaman yang komplek. $^{39}$ Meskipun metode tahlili diidentikkan dengan pekerjaan tafsir yang luas, kemudian pendekatan hermeneutik menggambarkan ijtihadi pemaknaan yang didasari horison ilmu pengetahuan almarhum sebagai penulis yang beraneka ragam, tetapi almarhum dalam bukunya dan praktek pengajaran tafsirnya tetap berusaha memberikan penjelasan yang memudahkan bagi pembaca untuk dipahami, dan inilah tugas mufassir yang utama. ${ }^{40}$

\section{Beberapa Pelajaran dan Pengamalan dari Surat Alfatihah}

Pertama, hubungan antara Khalik dengan makhluk. Bahwasanya Allah menunjukkan hubungan yang dikehendaki-Nya kepada makhluk-Nya agar selamat dunia akhirat. Untuk itu, Allah memberikan syariat (tata cara beribadah), akidah, dan manhaj hidup. Kemudian manusia perlu selalu bertanya kepada dirinya apakah jalan yang ditempuh sudah sesuai dengan yang dikehendaki Allah. Perjalanan yang harus ditempuh manusia harus terus ditelusuri lewat Alfatihah dan Alquran, boleh dengan niatan untuk pengobatan, kekuatan, kecukupan, atau lain-lainnya, dan yang paling utama adalah untuk menghubungkan diri kepada Allah.

Kedua, hendaknya sebagai makhluk senantiasa menghadirkan semua tuntutan Khalik ke dalam hati sanubari. Sebagai misal, saat lesan membaca

38 Mohammad Arja Imroni, op.cit., 6; M. Quraish Shihab, Tafsir Alquran A/Karim: Tafsiri atas Surat-surat Pendek Berdasarkan Urutan Turunnya Wahyu, (Bandung: Pustaka Hidayah, 1997), v-vii.

39 Mamat S. Burhanuddin, op.cit., 75.

40 Lihat pula penjelasan tim tashih dalam pengantarnya di Lajnah Mushaf Pentashihan Mushaf Alquran (LPMA), Tafsir Ringkas (J ilid 1), (J akarta: Lajnah Mushaf Pentashihan Mushaf Alquran, 2016), xxxiii-xlii. 
Alfatihah, maka hendaknya pikiran pembaca menghadirkan artinya dan hati merasakannya. J ika masih terlalu berat, dapat diturunkan tingkatannya sesuai kemampuan pembaca, misalnya dengan memotong per-asma' yang ada dalam Alfatihah, yang dapat dijadikan benang penghubung dengan Khaliq.

Ketiga, dalam Alfatihah dapat dipelajari dan dikenali konsep iltifat, yaitu perubahan arah pembicaaraan dari orang pertama (mutakallim) kepada orang kedua (mukhatab) atau kepada orang ketiga (ghaib), ataupun kebalikannya. Dalam Alfatihah dijumpai redaksi 'maliki yaumi d-din' yang merupakan pihak ketiga menuju 'iyyaka na'budu' yang merupakan pihak kedua. Perubahan khitab ini diharapkan menjadi acuan untuk memperkuat dan mempertekun ibadah agar semakin dekat kepada Allah.

Keempat, redaksi 'iyyaka nasta'in' dan 'ihdina' merupakan dalil akidah yang digunakan Ahlussunnah yang menyatakan bahwa semua 'af'al l-ibad' (perbuatan hamba) diciptakan oleh Allah, berbeda dengan Mu'tazilah yang menyatakan bahwa perbuatan hamba merupakan reka cipta manusia sendiri. ${ }^{41}$

\section{Langkah-Langkah Pengamalan ( uz 30, 29, dan 28)}

Langkah-langkah pengamalan yang dimaksud dan dicontohkan oleh K.H. Asyhari Marzuqi di sini memang difokuskan pada objek juz 30, 29, dan 28. Akan tetapi, jika dicermati, langkah-langkah pengamalan dan penyikapan terhadap surat ini dapat pula diterapkan dalam ayat atau surat selain tiga juz itu. Barangkali yang sedikit banyak membedakan dalam tiga juz ini adalah dari segi periodesasi turunnya ayat, yang umumnya merupakan surat Makkiyah. Ayat Makkiyah lebih banyak membahas tauhid, rukun iman, perbandingan (baik-buruk, untung-rugi, bahagia-celaka, terpuji-tercela, surganeraka, kafir-mukmin), dan beberapa ibrah sejarah. Sedangkan permasalahan syariat, mendapatkan porsi cukup hanya di juz 28 yang kebanyakan surat Madaniyah, itupun hanya beberapa tema saja. Untuk tema-tema syariah lainnya, termasuk rukum Islam, dapat digali dari surat-surat Madaniyah di juz lainnya. ${ }^{42}$

Langkah pengamalan yang disampaikan K.H. Asyhari dalam buku ini secara global sebagai berikut: Pertama, kewajiban umat Islam adalah meneruskan ajaran Alquran kepada generasi penerus, sembari memberikan contoh-contoh, mulai dari membaca, memahami, mentadabburi, dan mengamalkannya. Contoh dan cara untuk hal itu sudah banyak diberikan oleh

${ }^{41}$ Marzuqi, op.cit., 85-87.

42 Ibid, 92-171; Malik Madany, "Mengambil Hikmah dari Rangkuman Kisah" dalam Spiritualitas Alquran dalam Membangun Kearifan Umat, diedit oleh Moh. Mahfud MD, (Yogyakarta: UII Press, 1997), 352-354. 
para pendahulu, maka umat Islam yang sekarang perlu meneruskan dan melakukan pembaruan yang lebih sesuai dengan masanya.

Kedua, melakukan peningkatan bacaan, pemahaman, dan pengamalan. Bacaan yang diinginkan oleh umat Islam adalah taraf haqqa tilawatih. Untuk mencapai itu, langkah yang perlu ditempuh pembaca adalah membaca sesuai aturan yang ditetapkan para ulama, lalu mengetahui arti, dan berlanjut kepada lisan membaca, otak menterjemah, dan hati merasakan. Dari bacaan yang demikian akan menimbulkan kontak dari diri pembaca, yang bertingkat-tingkat sesuai konsentrasi dan dapat dilatih. Kontak tersebut adalah; Kontak lisan, sebagaimana yang diajarkan Nabi, bahwa dalam salat, saat membaca ayat rahmat, seorang muslim berhenti dan memohon rahmat, dan saat membaca ayat siksa, si muslim memohon perlindungan, dan lain sebagainya. Kontak mata, gambaran mudahnya adalah pembaca dapat mentadabburi bacaan hingga dapat mencucurkan air mata, atau bila tidak dapat menangis maka berpura-pura atau berusaha menangis. Kontak perilaku, adalah saat membaca, pembaca dapat merasakan bahwa dirinyalah yang mendapat dawuh dari Allah, sehingga mendapatkan dorongan batin untuk segera mengamalkannya.

Peningkatan pemahaman dan pengamalan dapat ditempuh dengan beberapa cara, antara lain:

a) Saat membaca ayat-ayat perbandingan, seperti iman-kufur, hak-batil, baikburuk, dan sebagainya, hendaknya pembaca berhenti dan menanyakan kepada pribadinya, 'dimanakah posisinya dalam perbandingan itu'. Jika ia berada dalam posisi yang positif, pembaca hendaknya bersyukur dan bertekad semakin meningkatkan hal positif itu. Sebaliknya jika berada dalam posisi negatif, pembaca segera ber-istigfar dan bertekad segera meninggalkannnya.

b) Kadangkala sifat positif dan negatif dalam ayat Alquran berdiri sendiri, tidak dibandingkan. Dalam hal ini, pembaca menanyakan kepada dirinya, 'sudahkan hal positif ini ada pada dirinya, dan sudahkan hal yang negatif ini lenyap dari dirinya?'

c) Dalam membaca ayat yang menjanjikan balasan surga atau ancaman neraka, pembaca menanyai dirinya, 'perilakunya menjurus kemana?' kemudian merenungi betapa pedihnya siksa neraka, bagaimana jika sampai disiksa di tempat itu, sebaliknya tentang nyamannya surga, lalu bagaimana jika ditolak masuk surga, dan seterusnya.

d) Saat membaca asma dan sifat Allah, para rasul, dan shalihin, pembaca bertanya, 'sudahkah ia dapat ber-takhalluq bi-akhlaqihim, sampai tingkat mana?' kemudian saat membaca kisah orang durhaka, 'sudahkah ia menghindarinya?' 
Selain pengetahuan tentang cara peningkatan pemahaman, ada tuntunan sikap yang perlu dilakukan pembaca sebelum membaca Alquran antara lain:

a) Keyakinan penuh bahwa Alquran yang dibaca merupakan firman Allah yang menjadi pedoman hidup yang harus dilaksanakan.

b) Memposisikan diri seakan berada di hadapan Allah untuk menerima firman, sehingga perlu memohon perlindungan, pemahaman, dan kekuatan untuk mengamalkan.

c) Saat membaca, menanyakan kepada pribadinya, 'di manakah hatinya, apakah dalam kondisi berkonsentrasi (hudhur al-qalbi) ataukah sedang condong pada urusan duniawi, dan berusaha mengesampingkan urusan duniawi yang menjadi tabir penghalang.

d) Berusaha menyertakan ketulusan, kemauan kerasa, dan kemantapan hati untuk mentadabburi saat membaca.

Ketiga, konsep-konsep kehidupan.Untuk membentuk konsep-konsep kehidupan yang qur'ani, umat Islam perlu berkiblat kepada para ahli, yaitu para ulama dan mujtahid ${ }^{43}$. Saat menghadapi perbedaan pendapat di antara para ulama, maka umat perlu bersikap hati-hati dan kembali merunut kepada pedoman yang sudah diyakini oleh ulama kebanyakan, dan lembaga pemerintah yang berwenang. ${ }^{44}$

\section{Penutup}

Kajian ini diharapkan menjadi pengingat bagi para pembaca, bahwa sebagai muslim, hendaknya selalu meningkatkan kemampuan membaca, memahami, dan mengamalkan Alquran sepenuh kemampuan. K.H. Asyhari Marzuqi mengajak para santri meningkatkan aktifitas berliterasi Alquran dan memberikan alternatif metode pembelajaran tafsir yang dapat ditiru. Metode yang dicontohkan almarhum sederhana, dan barangkali mirip dengan metode pembelajaran di pesantren lainnya, yaitu model sorogan dan bandongan. Akan tetapi, penawaran metode pengajaran tafsir dengan sorogan yang disertai diskusi, dapat dianggap baru, sebagai contoh sikap yang mempertahankan tradisi salaf yang patuh dengan tatacara keilmuan ulumul quran, sekaligus bijak dan tidak alergi terhadap metode penafsiran dan keilmuan baru. Sorogan yang dicontohkan almarhum dibekali dengan

43 Ulama dan mujtahid Alquran dan karyanya amat banyak tak terkira. Baik dari ulama Timur Tengah, Asia Tenggara, ataupun dari pandangan orientalis. Untuk ilmuwan Alquran di Asia Tenggara (Indonesia) misalnya dapat dilacak dari tulisan Howard M. Federspiel, Kajian Alquran di Indonesia: Dari Mahmud Yunus Hingga Quraish Shihab, (Bandung, Mizan, 1996).

${ }^{44} /$ bid, 117-121. 
muthalaah kitab-kitab tafsir, selanjutnya ustaz dan santri dapat berdikusi membahas ayat demi ayat dan surat demi surat terutama dari juz-juz akhir yang merupakan bekal pondasi tauhid dan bermasyarakat.

Buku Targhibul Khatir Fi al-Quran merupakan pengungkapan ide dan metode pembelajaran tafsir yang almarhum tuangkan dalam bentuk tulisan. Tatacara membaca, memahami, menyikapi, dan mengamalkan bacaan dari ayat dan surat dicontohkan dalam buku ini, terutama dalam juz 30-28. Dengan metode penafsiran tahlili K.H. Asyhari Marzuqi memberikan penjelasan, dan contoh-contoh menyikapi surat Alfatihah dan surat-surat juz akhir.

\section{Daftar Pustaka}

Al-Maraghi, Ahmad Musthafa. Tafsir Almaraghi: J uz 14. Beirut: Dar Ihya atTurats Al-Araby, 1985.

Armas, Adnin. Metodologi Bibel dalam Studi Alquran: Kajian Kritis. J akarta: Gema Insani Press, 2005.

Aziz, Muhammad Amin. Kedahsyatan Alfatihah: Solusi Islam pada Krisis Peradaban Umat Manusia. Semarang: Pustaka Nun, 2008.

Buku Profil Pondok Pesantren Nurul Ummah Kotagede Yogyakarta, tanpa tahun.

Burhanuddin, Mamat S. Hermeneutika Alquran ala Pesantren (Analisis terhadap Tafsir Marah Labid Karya K.H. Nawawi Banten). Yogyakarta: UII Press, 2006.

Chalwani, Ahmad. Profil Pondok Pesantren Nurul Ummah. Dalam https:// www. youtube. com/ watch?v=nN0gzZhjs9A\&t=370s, 2014, diakses pada September 2018.

Dhofier, Zamakhsyari. Tradisi Pesantren. J akarta: LP3ES, 1982.

Federspiel, Howard M. Kajian Alquran di Indonesia: dari Mahmud Yunus Hingga Quraish Shihab. Bandung: Mizan, 1996.

Faiz, Fahruddin. Hermenutika Alquran: Tema-tema Kontroversial. Yogyakarta: eLSAQ Press, 2005.

Ghazali, Abd Moqsith, et.all. Metodologi Studi Alquran.J akarta: PT Gramedia, 2009.

Gusmian, Islah. Khazanah Tafsir Indonesia, dari Hermeneutika hingga Ideologi. J ogjakarta; LKiS, 2013.

Hamid. Modal Sosial (Sosial Capital) di Pesantren Nurul Ummah, Studi tentang modal sosial pra dan pasca kepemimpinan K.H. Asyhari Marzuqi. Tesis. Fakultas Ilmu Sosial dan Politik Sekolah Pascasarjana UGM Y ogyakarta, 2010. 
Harahap, Syahrin. Metodologi Studi Tokoh \& Penulisan Biografi. Jakarta: Prenada, 2011.

Imroni, Mohamad Arja. Kontruksi Metodologi Tafsir Alqurthubi. Semarang: Walisongo Press, 2010.

J amaludin, Mahbub, dan Abdul Basith Rustami, editor. Mata Air Keikhlasan: Biografi K.H. Asyhari Marzuqi. Yogyakarta: Nurma Media Idea, 2009.

Lajnah Mushaf Pentashihan Mushaf Alquran (LPMA). Tafsir Ringkas ( $\mathrm{ilid} 1$ ). J akarta: Lajnah Mushaf Pentashihan Mushaf Alquran, 2016.

Madany, Malik. Mengambil Hikmah dari Rangkuman Kisah, dalam Spiritualitas Alquran dalam Membangun Kearifan Umat, diedit oleh Moh. Mahfud MD, 351-363. Yogyakarta: UII Press, 1997.

Mahalli, A. Mudjab. "Kisah-Kisah Pelipur Lara" dalam Spiritualitas Alquran dalam Membangun Kearifan Umat, diedit oleh Moh. Mahfud MD, 307328. Yogyakarta: UII Press, 1997.

Mahfud MD, Moh (ed.). Spiritualitas Alquran dalam Membangun Kearifan Umat. Yogyakarta: UII Press, 1997.

Maknun, Moch. Lukluil. "Implementasi Tradisi Ikhtilaf dan Budaya Damai pada Pesantren Nurul Ummah dan Ar-Romli Yogyakarta." Jurnal Analisa Vol. 21(02) 2014, 239-251. https:// doi.org/ 10.18784/ analisa.v21i02.18

Marzuqi, Asyhari. Targhib Al-Khatir Fi Alquran: Memikat Hati dengan Alquran. Yogyakarta: Nurma Media Idea, 2002.

Mulkhan, Abdul Munir. "Wacana Tafsir Multimetodologi dan Disiplin" dalam Spiritualitas Alquran dalam Membangun Kearifan Umat, diedit oleh Moh. Mahfud MD, 409-415. Yogyakarta: UII Press, 1997.

Nata, Abuddin. Perspektif Islam tentang Strategi Pembelajaran. Jakarta: Kencana, 2009.

Palmer, Richard E. Hermeneutika: Teori Baru Mengenai Interpretasi. Yogyakarta: Pustaka Pelajar, 2005.

Pari, Fariz, et.all. Upaya Integrasi Hermeneutika dalam Kajian Quran dan Hadis (Teori dan Apliaksi). Yogyakarta: Lembaga Penelitian UIN Sunan Kalijaga, 2012.

Setiawan, M. Nur Kholis. Alquran Kitab Sastra Terbesar. J ogjakarta: eLSAQ Press, 2005.

Sukamto. Kepemimpinan Kiai dalam Pesantren. Jakarta: Pustaka LP3S, 1999.

Syihab, M. Quraish. Rasionalitas Alquran: Studi Kritis atas Tafsir al-Manar. J akarta: Lentera Hati, 2006.

------. Membumikan Alquran: Fungsi dan Peran Wahyu dalam Kehidupan Masyarakat. Bandung: Mizan, 1992. 
------. Tafsir Alquran Al-Karim: Tafsir atas Surat-surat Pendek Berdasarkan Urutan Turunnya Wahyu. Bandung: Pustaka Hidayah, 1997.

Syurbasyi, Ahmad. Studi tentang Sejarah Perkembangan Tafsir Alquran A/Karim. J akarta: Kalam Mulia, 1999.

Trianto. Mendesain Model Pembelajaran Inovatif-Progresif: Konsep, Landasan, dan Implementasinya pada Kurikulum Tingkat Satuan Pendidikan (KTSP). J akarta: Kencana, 2010.

Zaid, Nasr Hamid Abu. Tekstualitas Alquran, Kritik terhadap Ulumul Quran. J ogjakarta: LKiS, 1993.

Ponpes Nurul Ummah. Manaqib Almagfurlah K.H. Asyhari Marzuqi (Pengasuh PP Nurul Ummah Kotagede) dalam https:// www.youtube.com/ watch?v=Yiqks4l7kE8, 2016, diakses pada September 2018.

Informan:

Athourrahman, Pengurus Ponpes Nurul Ummah

Ahmad Suparmin, Alumni Pengurus Ponpes Nurul Ummah

J auhar Hilal, Alumni program tahfiz dan Pengurus Ponpes Nurul Ummah

Ahmad Mubarok, Alumni program tahfiz dan Pengurus Ponpes Nurul Ummah M. Raudak dan Adriek L M, Pengurus dan Pengelola Madrasah Diniyah Nurul Ummah 